\title{
Gills as a glutathione-dependent metabolic barrier in Pacific oysters Crassostrea gigas: Absorption, metabolism and excretion of a model electrophile
}

\author{
Rafael Trevisan $^{\mathrm{a}, \mathrm{b}, *}$, Danielle F. Mello ${ }^{\mathrm{a}}$, Gabriel Delapedra ${ }^{\mathrm{a}}$, Danilo G.H. Silva ${ }^{\mathrm{c}}$, \\ Miriam Arl ${ }^{\mathrm{a}}$, Naissa M. Danielli ${ }^{\mathrm{a}}$, Marc Metian ${ }^{\mathrm{d}}$, Eduardo A. Almeida ${ }^{\mathrm{c}}$, Alcir L. Dafre ${ }^{\mathrm{a}}$ \\ a Department of Biochemistry, Federal University of Santa Catarina, 88040-900 Florianópolis, Brazil \\ ${ }^{\mathrm{b}}$ Department of Aquaculture, Federal University of Santa Catarina, 88034-001 Florianópolis, Brazil \\ c Department of Chemistry and Environmental Sciences, São Paulo State University, 15054-000 São José do Rio Preto, Brazil \\ ${ }^{\mathrm{d}}$ International Atomic Energy Agency-Environment Laboratories (IAEA-EL), 4a Quai Antoine 1er, MC-98000 Principality of Monaco, Monaco
}

\section{A R T I C L E I N F O}

\section{Article history:}

Received 16 October 2015

Received in revised form 21 January 2016

Accepted 23 January 2016

Available online 29 January 2016

\section{Keywords:}

Mercapturic acid pathway

Glutathione

Glutathione S-transferase

Gills

Bivalves

\begin{abstract}
A B S T R A C T
The mercapturic acid pathway (MAP) is a major phase II detoxification route, comprising the conjugation of electrophilic substances to glutathione (GSH) in a reaction catalyzed by glutathione S-transferase (GST) enzymes. In mammals, GSH-conjugates are exported from cells, and the GSH-constituent amino acids (Glu/Gly) are subsequently removed by ectopeptidases. The resulting Cys-conjugates are reabsorbed and, finally, a mercapturic acid is generated through $\mathrm{N}$-acetylation. This pathway, though very well characterized in mammals, is poorly studied in non-mammalian biological models, such as bivalve mollusks, which are key organisms in aquatic ecosystems, aquaculture activities and environmental studies. In the present work, the compound 1-chloro-2,4-dinitrobenzene (CDNB) was used as a model electrophile to study the MAP in Pacific oysters Crassostrea gigas. Animals were exposed to $10 \mu \mathrm{M}$ CDNB and MAP metabolites were followed over $24 \mathrm{~h}$ in the seawater and in oyster tissues (gills, digestive gland and hemolymph). A rapid decay was detected for CDNB in the seawater (half-life $1.7 \mathrm{~h}$ ), and MAP metabolites peaked in oyster tissues as soon as $15 \mathrm{~min}$ for the GSH-conjugate, $1 \mathrm{~h}$ for the Cys-conjugate, and $4 \mathrm{~h}$ for the final metabolite (mercapturic acid). Biokinetic modeling of the MAP supports the fast CDNB uptake and metabolism, and indicated that while gills are a key organ for absorption, initial biotransformation, and likely metabolite excretion, hemolymph is a possible milieu for metabolite transport along different tissues. CDNB-induced GSH depletion ( $4 \mathrm{~h}$ ) was followed by increased GST activity ( $24 \mathrm{~h}$ ) in the gills, but not in the digestive gland. Furthermore, the transcript levels of glutamate-cysteine ligase, coding for the rate limiting enzyme in GSH synthesis, and two phase II biotransformation genes (GSTpi and GSTo), presented a fast ( $4 \mathrm{~h}$ ) and robust ( $\sim-70$ fold) increase in the gills. Waterborne exposure to electrophilic compounds affected gills, but not digestive gland, while intramuscular exposure was able to modulate biochemical parameters in both tissues. This study is the first evidence of a fully functional and interorgan MAP pathway in bivalves. Hemolymph was shown to be responsible for the metabolic interplay among tissues, and gills, acting as a powerful GSH-dependent metabolic barrier against waterborne electrophilic substances, possibly also participating in metabolite excretion into the sea water. Altogether, experimental and modeled data fully agree with the existence of a classical mechanism for phase II xenobiotic metabolism and excretion in bivalves.
\end{abstract}

(c) 2016 Elsevier B.V. All rights reserved.

\section{Introduction}

Aquatic organisms rely on their surrounding environment for different biological processes such as feeding, gas exchange, excre-

\footnotetext{
* Corresponding author at: Department of Aquaculture, Federal University of Santa Catarina, 88034-001 Florianópolis, Brazil.

E-mail address: rafael.trevisan@gmail.com (R. Trevisan).
}

tion, reproduction and migration. Water bodies are often used as sink for pollutants originated from anthropogenic activities, receiving a number of potentially toxic chemicals such as pharmaceuticals, metals, nanomaterials, pesticides, polychlorinated biphenyls and polycyclic aromatic hydrocarbons (Mostofa et al., 2013). These substances pose a threat to the survival and reproduction of aquatic organisms, even though efficient cellular defense systems may counteract the deleterious effects of such hazardous compounds. 
Extracellular space

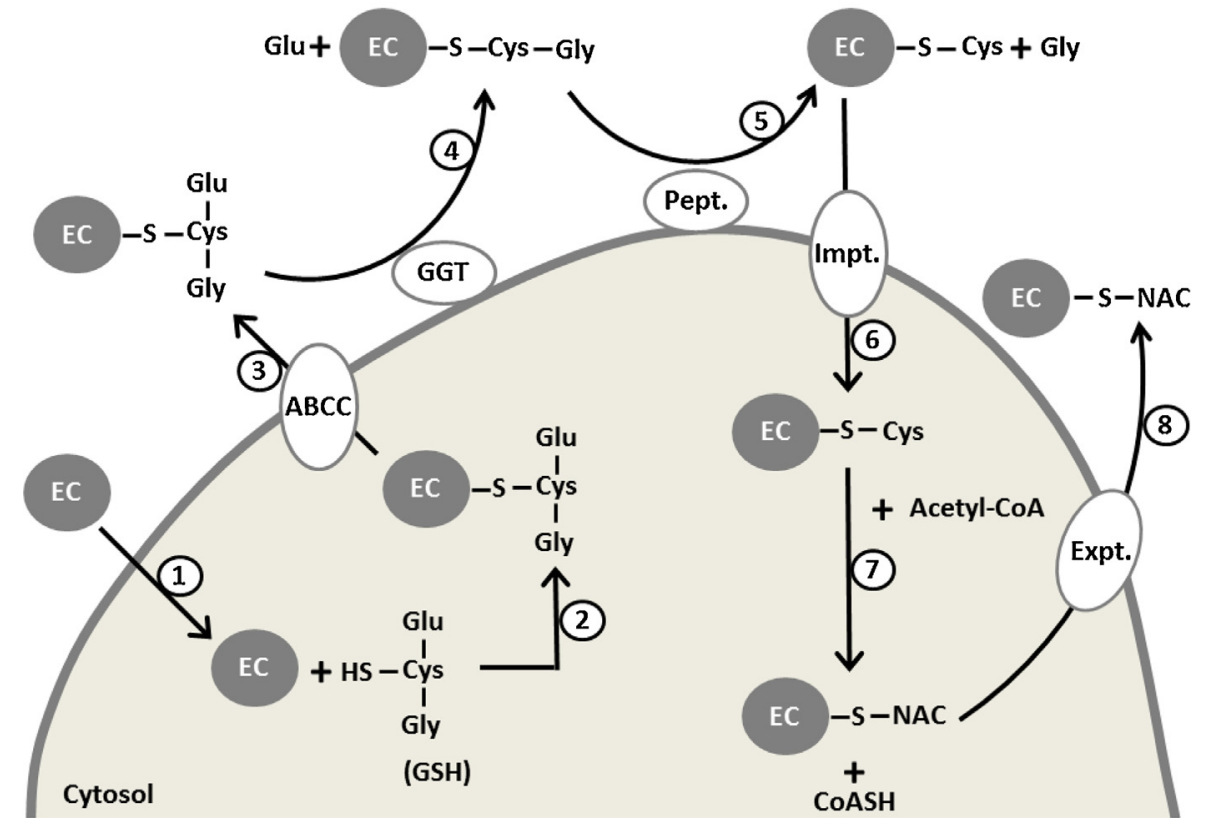

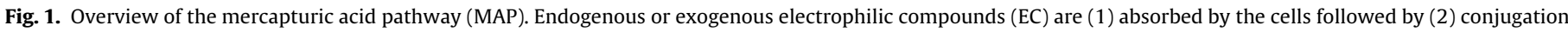

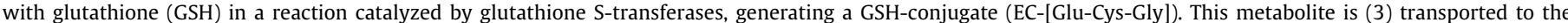

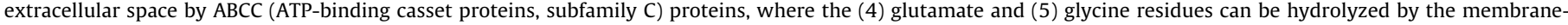

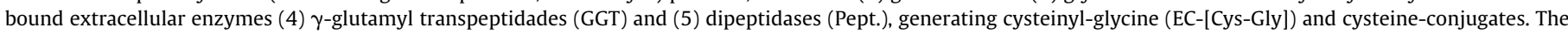

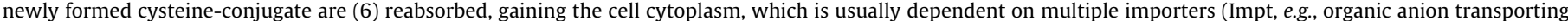

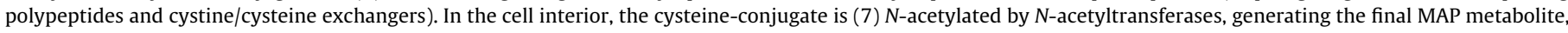

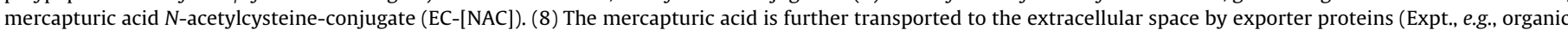

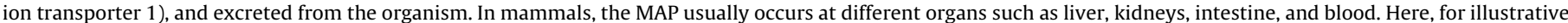
purposes, the MAP is shown in a single cell. Figure was adapted from Ramsay and Dilda (2014).

Bivalves are sessile, filter feeding organisms with high bioaccumulation capability (Hédouin et al., 2010), and thus are often subjected to the effects of aquatic pollutants. These characteristics, in addition to their widespread distribution and significant economic importance, have made bivalves an ideal model organism in aquatic toxicology and ecotoxicology studies to investigate and characterize the effects and mechanisms of toxicity for several pollutants (Apeti et al., 2010; Depledge and Fossi, 1994). For instance, studies have investigated the modulation of major defense systems (e.g., antioxidant and biotransformation) in bivalves exposed to environmental pollutants (Alolísio Torres et al., 2002; Borković et al., 2005; Dafre et al., 2004; de Almeida et al., 2004; Doyotte et al., 1997; Franco et al., 2006; Nogueira et al., 2015; Osman et al., 2007; Zanette et al., 2011). In this regard, gills and digestive gland are the most commonly studied tissues: gills are considered the main interface between the organism, environment and, consequently, waterborne pollutants (Ravera, 2001), while digestive gland is known as a major detoxification site due to the higher expression of the mixed-function oxidase system (Livingstone and Farrar, 1984; Solé and Livingstone, 2005). Thus, it is essential to characterize how different organs respond mutually to aquatic pollutants. Yet, it is still poorly known how they participate and coordinate the absorption, metabolism and excretion of organic contaminants (interorgan metabolism) in bivalves.

In bivalves, one of the most studied enzymes related to phase II of biotransformation is the glutathione S-transferase (GST), a protein responsible for conjugating electrophilic compounds (e.g., halogenonitrobenzenes, arene oxides, quinones, and $\alpha, \beta$ unsaturated carbonyls) with glutathione (GSH) (Board and Menon, 2013), which is the first step in the synthesis of mercapturic acids ( $N$-acetylcysteine conjugates) (Boyland and Chasseaud, 1969). These electrophilic compounds have the potential to react with different cellular targets, such as DNA, RNA and proteins, highlighting the importance of GSTs and conjugation with GSH to the cellular protection and prevention of electrophilic attacks to biomolecules. As extensively shown in mammals, GSH-conjugates originated by GST activity are further metabolized along the mercapturic acid pathway (MAP) before excretion (Hinchman et al., 1991), as follows (Fig. 1): (i) export of GSH-conjugates by ABCC (ATP-binding cassette, subfamily $C$ ) proteins to the extracellular environment; (ii) removal of the gamma-glutamyl and glycine moieties by the extracellular enzyme gamma-glutamyl transpeptidase (GGT) and dipeptidases, respectively; (iii) cysteinylconjugates are reabsorbed by multiple transporters (e.g., organic anion transporting polypeptides and cystine/cysteine exchangers) in specific cell types; (iv) these conjugates are acetylated by cytosolic $N$-acetyltransferases, thus generating a mercapturic acid ( $N$-acetylcysteine-conjugate) and increased hydrophilicity; (v) this metabolite can now be exported from cells through the organic ion transporter and excreted from the organism via urine or bile (Commandeur et al., 1995; Haufroid and Lison, 2005). In mammals, the mercapturic acid biosynthesis is characterized as an interorgan process, due to the participation of specific enzymes, which are mostly located in the liver, kidney and intestine (Hinchman and Ballatori, 1994; Villanueva et al., 2006).

In addition to mammals (Hayes et al., 2005), the MAP may be an important pathway of cellular defense to aquatic species, such as in the conjugation of GSH with phycotoxins (Malbrouck and Kestemont, 2006) or epoxide groups generated through cytochromes P450 (James, 1987). Detoxification of oxidative stress end products, such as 4-hydroxynonenal, are also GST substrates in aquatic organisms (Pham et al., 2002). MAP metabolites have been found in macrophytes, sea urchins and fishes exposed to polycyclic aromatic hydrocarbons, herbicides, epoxides or micro- 
cystins (Lay and Menn 1979; Malins and Roubal, 1982; Yagen et al., 1984; Pflugmacher, 2004). To our knowledge there are no studies indicating the presence of MAP metabolites in bivalves exposed to pollutants, although they unquestionably accumulate MAP metabolites and upregulate GSH, GST and ABC proteins when exposed to environmental toxins (Abraham et al., 2012; Burmester et al., 2012; Chen and Xie, 2005; Choi et al., 2006; Contardo-Jara et al., 2008; Wang et al., 2004). This lack of chemical data does not imply that the MAP has a secondary role on the biotransformation of organic contaminants in bivalves. In fact, some studies suggest that conjugation with GSH (the initial MAP step) is an important detoxification pathway in these organisms. For example, when GSTs purified from clams were incubated in vitro with a mixture of PCBs, authors suggested that a PCB-GSH conjugate was formed (Blanchette and Singh, 2003). Moreover, the elimination of organophosphate pesticides by mussels can be increased by previous upregulation of GSH and GST, hence likely increasing the GSH-conjugation reaction (Peña-Llopis et al., 2014). Finally, GST upregulation is usually found when bivalves are exposed to organic contaminants, which have been commonly suggested as protective effect against the chemical stress (Liu et al., 2014; Lüchmann et al., 2014). In bivalves, the MAP may be deeply associated with the metabolism of lipid peroxidation end-products (e.g., epoxyaldehydes, ketoaldehydes, 2-alkenals and 4-hydroxy-2-alkenals), whose production can be affected by abiotic and biotic factors, including seasonality, oxygen levels, feeding and reproduction (Canesi, 2015). But it is reasonable to assume that in these organisms the MAP may also participate in the detoxification of environmental contaminants such as pharmaceuticals, industrial intermediates and pesticides.

The compound 1-chloro-2,4-dinitrobenzene (CDNB) is a benzene derivate routinely used as a general substrate for GST activity assays (Habig and Jakoby, 1981), producing the GSH-conjugate 2,4dinitrophenyl-glutathione (DNP-SG). Therefore, it is possible to investigate the mercapturic acid biosynthesis following an exposure to CDNB, which begins with the intracellular formation of DNP-SG and further biotransformation, transport and excretion events. This strategy has already been successfully employed in mammals and has allowed the identification of organs acting as important barriers, such as placenta (Vaidya et al., 2011), intestine (Uršič et al., 2009) and choroid plexus (Ghersi-Egea et al., 2006), as well as organs with intense metabolism, such as liver (Villanueva et al., 2005) and kidneys (Terlouw et al., 2001). Cancer cells also present a strong activity of CDNB conjugation with GSH, followed by an efficient DNP-SG excretion, which can provide to these cells a higher resistance to electrophilic compounds such as some pharmaceuticals (Zhang and Wong, 1996).

The few non-mammalian models used to investigate the MAP following CDNB exposure include bacteria (Zablotowicz et al., 1995), plants (Schröder et al., 2007), and in vitro assays with fish hepatocytes or red blood cells (Simmons et al., 1991; Stoelting and Tjeerdema, 2000). Regarding bivalves, a previous study reported GSH consumption and increased GST activity in the gills of oysters Crassostrea gigas exposed to CDNB, in addition to an increasing development of a yellowish color in the seawater, which had a strong absorption at $340 \mathrm{~nm}$ and was possibly related to CDNB metabolites excreted from oysters (Trevisan et al., 2012).

No previous study has characterized the sequential and coordinated steps of MAP in bivalves; neither investigated the importance of a particular tissue in this route. An acute waterborne exposure of oysters $C$. gigas to CDNB was chosen as a first approach to characterize the MAP in bivalves. In this study, we focused on metabolite analysis, biokinetic modeling, molecular and biochemical analyses; and used gills, digestive and hemolymph as representative tissues with potential involvement in the MAP.

\section{Material and methods}

\subsection{Animals and acclimation}

Adult male and female oysters $C$. gigas (length: 9-14 cm; wet weight of soft parts: $22.3 \pm 6.4 \mathrm{~g}$ ) were obtained from an oyster farming facility from Ribeirão da Ilha (Florianópolis, Brazil). Animals were acclimated for 7 days in tanks containing filtered and UV-sterilized seawater (density of 1 animal L ${ }^{-1}$ ) with constant temperature $18-20^{\circ} \mathrm{C}$ and fed with plankton-based commercial food for filtering invertebrates (Sera Marin Coraliquid, Sera; Germany). All experiments were carried out according to the local Research Ethics Committee at Federal University of Santa Catarina.

\subsection{In vivo exposure to CDNB for metabolite analysis}

Animals were exposed to waterborne CDNB to investigate the MAP. For this purpose, oysters $(n=6)$ were individually exposed to $10 \mu \mathrm{M} \mathrm{CDNB}\left(1 \mathrm{~L}\right.$ animal $\left.^{-1}\right)$ for $24 \mathrm{~h}$ in glass flasks. Seawater aliquots were collected over $24 \mathrm{~h}$ (at indicated time points) and used for the quantification of CDNB and MAP-related metabolites.

The levels of MAP-related metabolites were also quantified in oyster gills, digestive gland and hemolymph in a parallel experiment. Animals $(n=3-6)$ were exposed to $10 \mu \mathrm{M}$ CDNB $(1 \mathrm{~L}$ animal $^{-1}$ ) in glass aquaria for $24 \mathrm{~h}$ and tissues were collected at indicated time points.

All experimental groups were exposed to the same CDNB vehicle concentration $(0.01 \%$ ethanol).

\subsection{In vivo exposure to waterborne and intramuscular CDNB for molecular and biochemical assays}

The effects of CDNB on antioxidant and biotransformation related-parameters in the gills and digestive gland were investigated in oysters $(n=12)$ exposed to $10 \mu \mathrm{M}$ waterborne CDNB (conditions similar to Section 2.2) for $24 \mathrm{~h}$ in glass aquaria. Gills and digestive gland were collected at different time points, depending on the analysis.

Intramuscular exposure occurred by injecting 0.3-3 $\mu \mathrm{mol}$ CDNB (in $1 \mathrm{~mL}$ ) through a notch in the valves directly into the oysters' adductor muscle using a $1 \mathrm{~mL}$ syringe coupled to a 23-gauge needle. Due to the low solubility of CDNB in the seawater, and in order to achieve seawater and hemolymph osmolarity, CDNB was previously prepared in absolute ethanol and further diluted in the inert sugar xylose ( $1 \mathrm{M}$ xylose and $0.01 \%$ ethanol). After the injection, animals $(n=8)$ were maintained for $24 \mathrm{~h}$ in clean seawater, and tissues (gills and digestive gland) were collected. CDNB doses injected in the adductor muscle can be compared to waterborne CDNB exposures ranging from 0.3 to $3 \mu \mathrm{M}\left(0.3\right.$ to $3 \mu \mathrm{mol} \mathrm{L}^{-1}$ animal $\left.^{-1}\right)$. Due to solubility issues, it was not possible to achieve higher doses, compatible with $10 \mu \mathrm{M}$ waterborne CDNB.

\subsection{In vivo exposure to $\mathrm{N}$-ethylmaleimide (NEM)}

The electrophilic, thiol depleting and membrane permeable compound $\mathrm{N}$-ethylmaleimide (NEM) was used to study the importance of GSH as a metabolic barrier in the gills, protecting other tissues against electrophilic substances. Similarly to CDNB, oyster NEM exposures were waterborne $\left(1-1000 \mu \mathrm{M}, 1 \mathrm{~L}^{2}\right.$ animal $\left.{ }^{-1}\right)$ or intramuscular (10-300 $\mu$ mol dissolved in $1 \mathrm{~mL}$ seawater). After $1 \mathrm{~h}$ of exposure, gills and digestive gland were collected for GSH determination $(n=9-12)$. NEM doses injected in the adductor muscle can be compared to waterborne NEM exposures ranging from 10 to $300 \mu \mathrm{M}\left(10-300 \mu \mathrm{mol} \mathrm{L}^{-1}\right.$ animal $\left.^{-1}\right)$. 


\subsection{In vitro exposure of gills and digestive gland extracts to CDNB and DNP-SG}

Comparative determination of in vitro DNP-SG synthesis and degradation rates were investigated in the gills and digestive gland. Tissues from control organisms ( $100 \mathrm{mg}$ wet weight; $n=3$ ) were homogenized $(1: 5 \mathrm{w}: \mathrm{v})$ in $20 \mathrm{mM}$ HEPES buffer $\mathrm{pH}$ 7.0. DNP-SG degradation rate was determined in crude extracts incubated at $20^{\circ} \mathrm{C}$ with $100 \mu \mathrm{M}$ DNP-SG (synthetized as described in Section $2.6)$ over a $24 \mathrm{~h}$ period. DNP-SG synthesis rate was determined in the $20,000 \times \mathrm{g}$ supernatant $\left(30 \mathrm{~min}\right.$ at $\left.4{ }^{\circ} \mathrm{C}\right)$ incubated at $20^{\circ} \mathrm{C}$ with $100 \mu \mathrm{M}$ of both CDNB and GSH over a $100 \mathrm{~min}$ period. In both analyses, a concentration of $2 \mathrm{mg}$ protein $\mathrm{mL}^{-1}$ was used.

\subsection{Synthesis of HPLC standards}

For DNP-SG synthesis, GSH and CDNB ( $1 \mathrm{mM}$ final concentration each) were incubated during $4 \mathrm{~h}$ in $1 \mathrm{~mL}$ of potassium phosphate buffer (KPi) $0.1 \mathrm{M} \mathrm{pH} 7.0$ containing $0.25 \mathrm{mM}$ EDTA and $1.5 \mu \mathrm{g}$ of purified GST from equine liver.

Both 2,4-dinitrophenyl conjugates of cysteine (DNP-Cys) and $\mathrm{N}$-acetylcysteine (DPN-NAC) were chemically synthesized using a standard protocol with 1-fluoro-2,4-dinitrobenzene (FDNB) as derivatizing agent (Hinchman et al., 1991). For DNP-Cys, $2.5 \mathrm{mmol}$ of FDNB (diluted in $25 \mathrm{~mL}$ of methanol) were slowly added to $12.5 \mathrm{~mL}$ of $\mathrm{KHCO}_{3} 2 \mathrm{~N}$ containing $2.5 \mathrm{mmol}$ of cysteine. This solution was stirred for $15 \mathrm{~min}$ and further acidified to $\mathrm{pH} 2$ with dilute $\mathrm{HCl}$. The precipitate was collected by vacuum filtration and recrystallized from boiling water. DNP-NAC was prepared as described above, except for the use of $5 \mathrm{mmol}$ of FDNB in $5 \mathrm{~mL}$ of methanol, and $5 \mathrm{mmol}$ of $\mathrm{N}$-acetylcysteine in $25 \mathrm{~mL}$ of $1 \mathrm{~N} \mathrm{KHCO}_{3}$. It was not possible to synthesize the 2,4-dinitrophenyl-cysteinylglycine conjugate (DNP-CG) due to its low stability (Vaidya and Gerk, 2007).

The extinction coefficient $(340 \mathrm{~nm})$ of DNP-SG $\left(10.3 \mathrm{mM}^{-1} \times \mathrm{cm}^{-1}\right)$, DNP-Cys $\left(9.0 \mathrm{mM}^{-1} \times \mathrm{cm}^{-1}\right)$ and DNPNAC $\left(9.9 \mathrm{mM}^{-1} \times \mathrm{cm}^{-1}\right)$ were used to calculate the concentration of these CDNB metabolites (Hinchman et al., 1991). The standards were validated by HPLC analysis of the metabolites generated in vitro by mouse liver and kidney homogenates incubated with GSH and CDNB or DNP-SG (same protocol as described for oyster tissues in Section 2.5).

\subsection{HPLC analysis of CDNB and metabolites in tissues and seawater}

CDNB, DNP-SG, DNP-Cys and DNP-NAC levels were determined in the seawater and tissues after CDNB exposure as described in Section 2.2. Seawater samples $(n=3-6)$ were acidified with perchloric acid (PCA, final concentration 5\%). Gills and digestive gland $(300 \mathrm{mg}$, $n=6$ ) were homogenized (1:3 w:v) in TRIS/HCl $0.1 \mathrm{M}$ buffer $\mathrm{pH} 8.0$, while hemolymph samples were assayed at the cell-free supernatant $\left(1,000 \times \mathrm{g}\right.$ for $10 \mathrm{~min}$ at $\left.4{ }^{\circ} \mathrm{C}\right)$. All samples (seawater and tissues) were acidified to $5 \%$ PCA, centrifuged at $15,000 \times g$ for $2 \mathrm{~min}$, and the supernatant diluted (5-35 times) and filtered with disposable $0.22 \mu \mathrm{m}$ filters.

Samples and standards were analyzed by HPLC using an ACE C18 column $(250 \times 4.6 \mathrm{~mm}, 5 \mu \mathrm{m})$ fitted with a guard column cartridge of the same composition, following an isocratic elution protocol (Hinchman et al., 1991) with some minor modifications. The HPLC system consisted of an ESA584 pump and an ESA526 UV/vis detector. Chromatogram monitoring, peak identification and quantification were performed using the EZ Chrom Elite software (Agilent Technologies, Santa Clara, CA, USA). Column temperature was adjusted to $30^{\circ} \mathrm{C}$ with a constant flow rate of $1 \mathrm{~mL} \mathrm{~min}^{-1}$ (100-110 bar) and $100 \mu \mathrm{L}$ of sample were used. For CDNB determination, the mobile phase consisted of $40 \%$ acetonitrile and $60 \%$
Table 1

Selected genes with their respective primers used for qPCR analyses and accession numbers from GenBank.

\begin{tabular}{lll}
\hline Gene & Sequence $5^{\prime}-3^{\prime}$ & GenBank \\
\hline GSTo & Fw-TGATGAGTTCACCACCGCAA & AJ557141.1 \\
& Rv-TTCAAACCATGGCCACAGCA & \\
GSTpi & Fw-AGGCGATTTCACCTCTGTC & AJ557140.1 \\
& Rv-TTCCTTCTGCCACAAAGTCG & \\
GSTmu & Fw-ACAAACCTTGGTTCGCTGGA & AJ558252.1 \\
& Rv-AGGCTTCATCAGTCTGTGCT & \\
GCL & Fw-TCACAGAGCCTCAGGTAAGT & EKC28200.1 \\
& Rv-GTCGTAGTTAATGCGGTCAG & \\
GAPDH & Fw-GCTGTGACACCATTGGAGAA & AJ5448886.1 \\
& Rv-ACCAATGACGCAACAAGCGA & \\
\hline
\end{tabular}

dilute acetic acid (1\%), and the chromatogram was recorded at $280 \mathrm{~nm}$. For DNP-SG and other CDNB metabolites, the mobile phase consisted of $25 \%$ acetonitrile and $75 \%$ dilute acetic acid (1\%), and the chromatogram was recorded at $340 \mathrm{~nm}$. Representative chromatograms for CDNB, DNP-SG, DNP-Cys and DNP-NAC analysis are available as Supplementary Figs. 1 and 2.

\subsection{Biochemical analyses in the gills and digestive gland}

For total glutathione measurement (the sum of reduced and oxidized forms, defined as GSH in the text), gills and digestive gland (50 mg; $n=12$ ) were freshly homogenized in 0.5 M PCA $(1: 10 \mathrm{w}: \mathrm{v})$ and centrifuged at $15,000 \mathrm{~g}$ for $2 \mathrm{~min}$ at $4{ }^{\circ} \mathrm{C}$. Supernatants were assayed spectrophotometrically at $412 \mathrm{~nm}$ using an enzymaticcoupled method (Akerboom and Sies, 1981).

For enzymatic measurements, tissues (300 mg; $n=12$ ) were homogenized ( $1: 4 \mathrm{w}: \mathrm{v})$ in $20 \mathrm{mM}$ HEPES and $2 \mathrm{mM}$ PMSF and centrifuged at $1,000 \times g$ for $5 \mathrm{~min}$ at $4{ }^{\circ} \mathrm{C}$. The pellet was discarded and an aliquot of the supernatant was separated to quantify GGT activity in the presence of glycylglycine and $\gamma$-glutamyl-p-nitroanilide at $405 \mathrm{~nm}$ (Silber et al., 1986). The remaining supernatant was further centrifuged at $20,000 \times \mathrm{g}$ for $30 \mathrm{~min}$ at $4{ }^{\circ} \mathrm{C}$ and the supernatant used for enzymatic assays. GST activity was assayed using CDNB and GSH as substrates at $340 \mathrm{~nm}$ (Habig and Jakoby, 1981); glutathione reductase (GR) activity was assayed at $340 \mathrm{~nm}$ following the reduction of oxidized GSH in the presence of NAPDH (Carlberg and Mannervik, 1985); and thioredoxin reductase (TrxR) activity was assayed at $412 \mathrm{~nm}$ following the reduction of DTNB in the presence of NADPH (Arnér et al., 1999). Protein content was estimated with Coomassie blue (Bradford, 1976), using bovine serum albumin as standard.

\subsection{Quantitative real-time PCR ( $q P C R$ )}

After exposure to $10 \mu \mathrm{M}$ waterborne CDNB at the indicated time points (details in Section 2.3), gills and digestive gland ( $50 \mathrm{mg} ; \mathrm{n}=4$ ) were stored at $-80^{\circ} \mathrm{C}$ using RNAlater ${ }^{\circledR}$ (Invitrogen, Brazil). Total RNA extraction, DNase I treatment and cDNA synthesis were performed following a previous protocol (Mello et al., 2012). Agarose (1\%) gel electrophoresis was performed to check for RNA integrity, while RNA concentration $\left(A_{260}\right)$ and purity $\left(A_{260 / 280}\right.$ and $\left.A_{260 / 230}\right)$ were estimated spectrophotometrically (NanoVue, GE Healthcare, Sweden).

The relative mRNA levels of the GST isoforms omega (GSTo), pi (GSTpi) and mu (GSTmu), and glutamate-cysteine ligase (GCL) were assayed by qPCR. Primers (Table 1 ) were chosen based on the literature or were selected based on specific $C$. gigas sequences deposited in GenBank. Only primers with efficiency between 1.8 and 2.2 were used. All qPCR analyses were performed in duplicates as previously described (Mello et al., 2012), using the ABI 7900HT thermocy- 
cler (Applied Biosystems, Brazil). The mRNA levels are expressed as fold change between control and treatment groups, normalized by the reference gene glyceraldehyde 3-phosphate dehydrogenase (GAPDH) using the $2^{-\Delta \Delta \mathrm{ct}}$ method (Livak and Schmittgen, 2001).

\subsection{Biokinetic modeling}

\subsubsection{Uptake phase}

In order to characterize the CDNB uptake, the decrease of CDNB in the seawater was assumed to be the amount of CDNB actively taken up by the oysters, and relativized to the average soft tissue weight $(22.3 \pm 6.4 \mathrm{~g})$. The concentration of CDNB was expressed in terms of concentration factor, $\mathrm{CF}$ ( viz. the ratio between whole soft part concentration - $\mu \mathrm{mol} \mathrm{Kg}{ }^{-1}$ wet weight - and time-integrated concentration of CDNB in the seawater $-\mu \mathrm{mol} \mathrm{L}^{-1}$, Renaud et al., 2014). The CF was used to estimate the total CDNB uptake efficiency of the oyster without taking into account any metabolism processes. CDNB uptake kinetics was described either as a simple linear regression model (Eq. (1)) or a simple exponential kinetic model (Eq. (2)) when observed kinetics tended to reach a steady state:

$\mathrm{CF}_{t}=k_{\mathrm{u}} t$

$\mathrm{CF}_{t}=\mathrm{CF}_{\mathrm{ss}}\left(1-\mathrm{e}^{-\mathrm{ket}}\right)$

where $\mathrm{CF}_{t}$ and $\mathrm{CF}_{\mathrm{ss}}\left(\mathrm{CF}_{\mathrm{sS}}=\mathrm{k}_{\mathrm{u}} / \mathrm{k}_{\mathrm{e}}\right)$ are the concentration factors at time $t(\mathrm{~h})$ and at steady state, respectively; and $k_{\mathrm{u}}$ and $k_{\mathrm{e}}$ are the uptake and loss rate constants $\left(\mu \mathrm{mol} \mathrm{Kg}{ }^{-1} \mathrm{~h}^{-1}\right)$, respectively. Although observed uptake kinetics tended to reach a steady state for the entire duration of experiment (thus would have been best described by a simple exponential kinetic model), the uptake kinetics was also assessed for the first $10 \mathrm{~h}$ (estimation made between $0-1 \mathrm{~h}, 0-4 \mathrm{~h}, 0-7 \mathrm{~h}$ and $0-10 \mathrm{~h}$ ) due to the potential effect on limiting availability of waterborne CDNB at the end of the experiment. Indeed, no adjustment of CDNB concentration in the aquaria was performed and a low CDNB concentration may lead to a reduction in the uptake rate constant or a biased measurement.

\subsubsection{Depuration phase}

In order to model the depuration of metabolites (DNP-SG, DNP-CYS and DNP-NAC; in concentration $-\mu \mathrm{mol} \mathrm{Kg}^{-1}$ wet weight or $\mu \mathrm{mol} \mathrm{L}^{-1}$ ) within a given tissue (gills, digestive gland or hemolymph), depuration kinetics were described by a singleexponential depuration model (Eq. (3)) or a linear depuration model (Eq. (4))

$$
\begin{aligned}
C_{t} & =C_{0} \mathrm{e}^{-\mathrm{ke} t} \\
C_{t} & =a-\left(k_{\mathrm{e}} t\right)
\end{aligned}
$$

where $C_{\mathrm{t}}$ and $C_{0}$ are the remaining concentration ( $\mu \mathrm{mol} \mathrm{Kg}{ }^{-1}$ wet weight for gills and digestive gland, or $\mu \mathrm{mol} \mathrm{L}^{-1}$ for hemolymph) at time $t(\mathrm{~h})$ and 0 , respectively; $k_{\mathrm{e}}$ is the depuration rate constant $\left(\mu \mathrm{mol} \mathrm{Kg}{ }^{-1} \mathrm{~h}^{-1}\right)$; a is a constant and the $y$ intercept when $t=0$; a biological half-life can be calculated $\left(T_{\mathrm{b}^{1 / 2}}\right)$ from the depuration rate constant according to the relation $T_{\mathrm{b} 1 / 2}=\ln 2 / k_{\mathrm{e}}$. Depuration phase was considered from the moment the component reached the highest concentration in a given tissues.

At the same time, as the decrease of dissolved CDNB concentration in the seawater was also described by a single-component model (Eq. (3)) and as oysters may have excreted CDNB metabolites (DNP-SG, DNP-CYS and DNP-NAC) to seawater, the depuration process (excretion rates) from the oysters was measured based on metabolite concentration in the seawater. Biokinetic model used to describe the increase of depurated metabolites levels in the seawater from oyster followed a linear model,

$A_{t}=k_{\mathrm{w}} t$
(Eq. (5); adapted from Eq. (1))where $A_{\mathrm{t}}$ is the concentration of the component at time $t(\mathrm{~h}) ; k_{\mathrm{w}}$ is the appearance rate constant of the component in the seawater $\left(\mu \mathrm{mol} \mathrm{h}^{-1}\right)$. Similarly to the uptake phase, the component appearance is driven by limiting availability of CDNB during the course of experiment (especially at the end). A simple exponential kinetic model would have slightly best described the appearance of the compound but this may be linked to the methodology selection (single spiked exposure).

\subsection{Statistical analysis}

Data were checked for normal distribution based on D'Agostino \& Pearson omnibus normality test. Data were analyzed by one-way ANOVA followed by post hoc test of Duncan or by Kruskal-Wallis test. Differences were considered as statistically significant when $p<0.05$. For the in vitro metabolism, data were analyzed by fitting one-phase decay (DNP-SG degradation) or one-phase association (DNP-SG synthesis) curves followed by extra sum of squares $F$ test for the $K$ values.

Regarding biokinetic analyses, constants of the models and their statistics were in general estimated by iterative adjustments of the model and Hessian matrix computation using the nonlinear curvefitting routines in the Statistica ${ }^{\circledR}$ 5.2.1 software. Other biokinetic models were tested but best fitting regression models were selected according to highest determination coefficient and examination of residuals (Metian et al., 2010). The level of significance for statistical analyses was set at $p=0.05$.

\section{Results}

\subsection{Absorption, metabolism and excretion of CDNB}

To investigate the MAP-related biotransformation steps of electrophilic compounds in bivalves, as well as the probable roles of gills, digestive gland and hemolymph in such steps, oysters $C$. gigas were exposed to waterborne $10 \mu \mathrm{M}$ CDNB for up to $24 \mathrm{~h}$, and seawater and tissues were collected over time. CDNB concentration analysis in the seawater indicated a short half-life for this compound, approximately $1.7 \mathrm{~h}$ (Fig. 2A), probably due to a fast absorption and bioconcentration by the organisms. After $10 \mathrm{~h}$ of exposure, only $5 \%$ of the initial CDNB levels were available in the seawater, which reinforces this hypothesis. CDNB bioconcentration kinetics were based on CDNB disappearance from seawater and best described by a first-order saturation model (Fig. 2B). Due to the potential effect on limiting availability of CDNB at the end of the experiment, data were analyzed between 0 and $10 \mathrm{~h}$. Biokinetic modeling points to a fast CDNB bioconcentration (concentration factor, $C F$ ) by $C$. gigas, exceeding steady-state water CDNB levels by $141.7 \pm 34.3$ times $(p<0.001)$. This can be explained by a fast uptake rate constant, estimated as $18.4 \pm 2.72\left(\mathrm{~L} \mathrm{~kg}^{-1} \mathrm{~h}^{-1}, p<0.001\right)$. In order to have an improved approximation of the maximum CDNB uptake rate constant, a linear model for the first hour of exposure was used and estimated an uptake rate of $30.9 \pm 2.04\left(\mathrm{~L} \mathrm{~kg}^{-1} \mathrm{~h}^{-1}\right.$, $p<0.0001$ ) or approximately $4.1 \mu \mathrm{mol}$ (CDNB) per hour per organism (data not shown). This estimate could reflect the best case scenario for determining the uptake rate without any biological limitations (e.g., depuration, metabolism).

It was not possible to validate these parameters by determining CDNB levels in tissues, as CDNB levels were below the limit of detection $(10 \mathrm{pmol} / 100 \mu \mathrm{L}$ sample) after the necessary dilution step prior to HPLC analysis. It is possible that CDNB was not detected at traceable levels in tissues due to a fast metabolism of $C$. gigas. Indeed, MAP metabolites (DNP-SG, DNP-CYS and DNP-NAC) analysis revealed a rapid and effective CDNB biotransformation in this species. During the initial minutes of exposure, a robust 
(A)

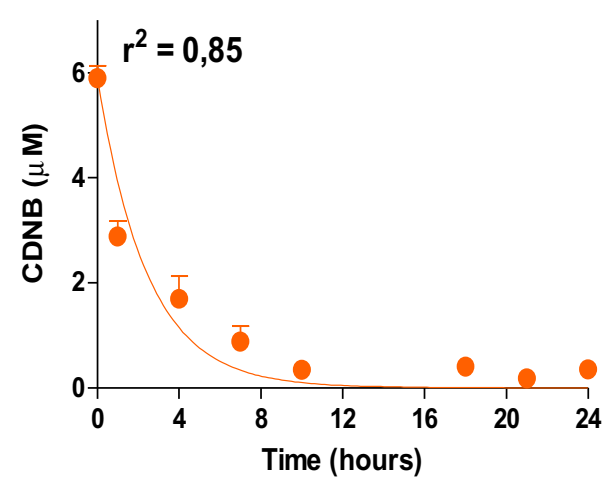

(B)

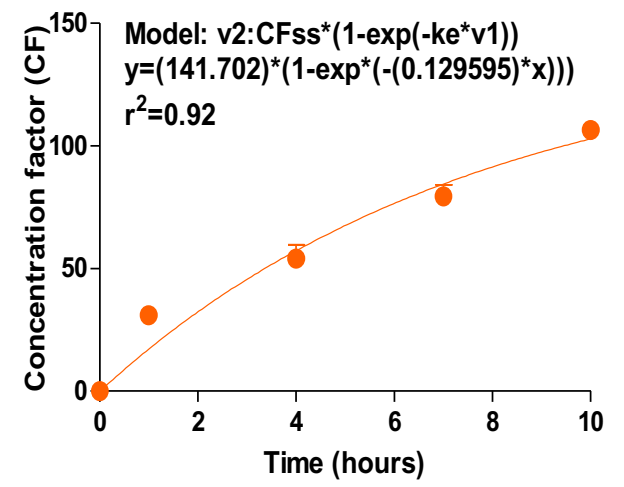

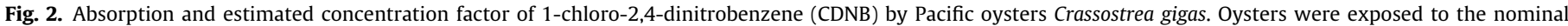

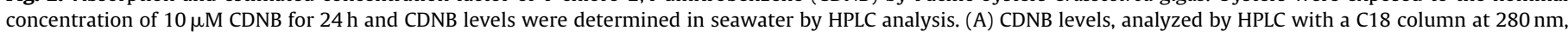

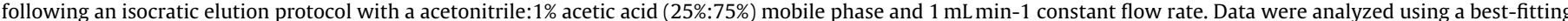

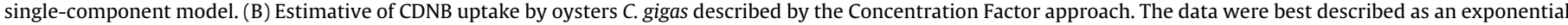
model and are presented as average + SEM $(n=3-6)$.

(A)

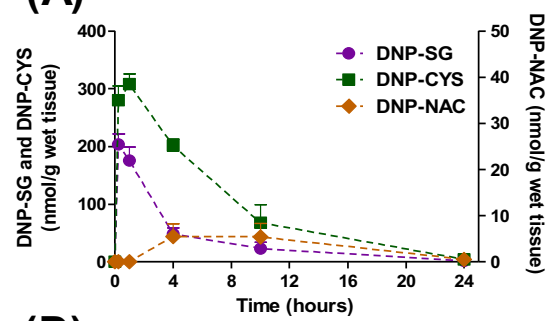

(D)

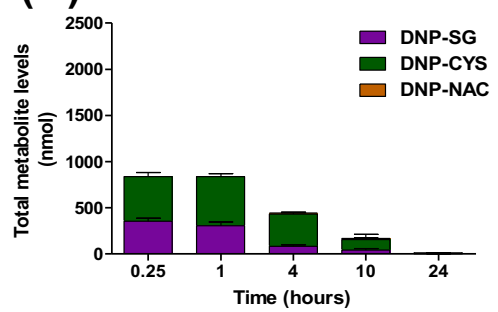

(G)

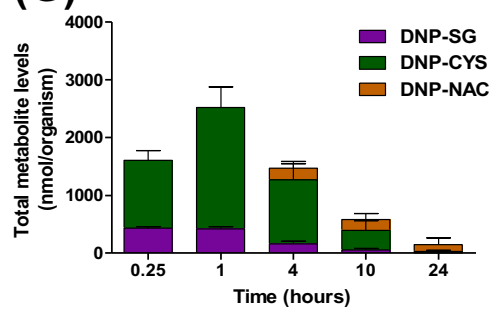

(B)

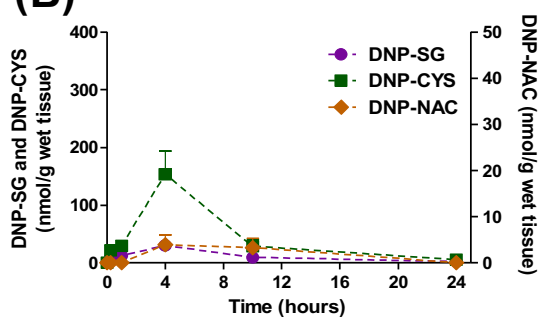

(E)

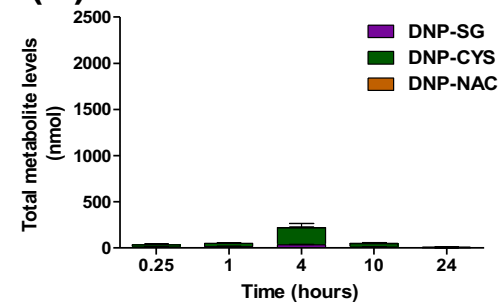

(H)

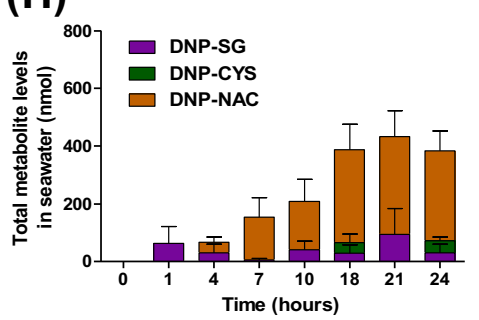

(C)

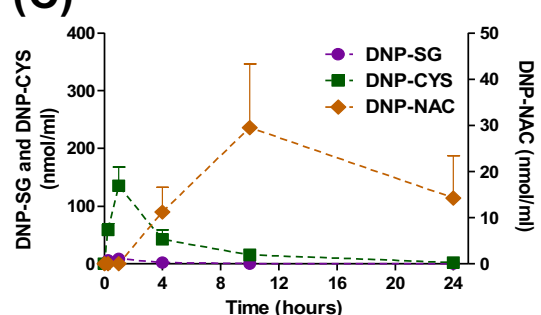

(F)

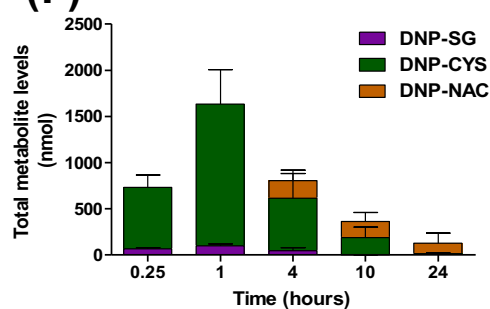

(I)

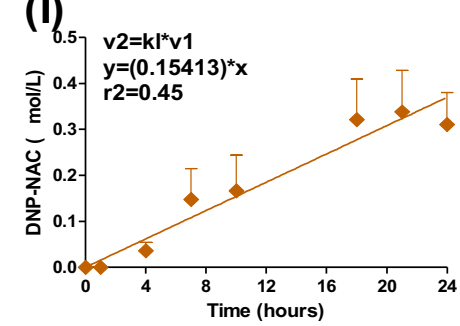

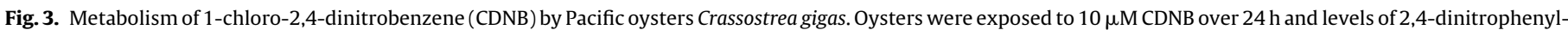

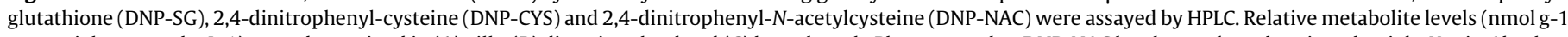

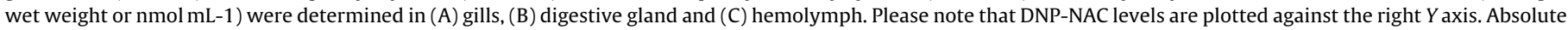

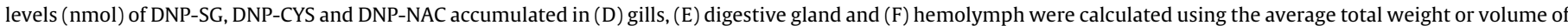

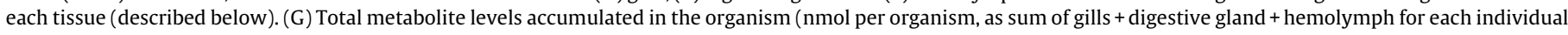

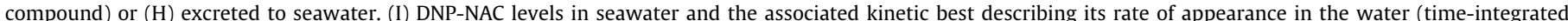

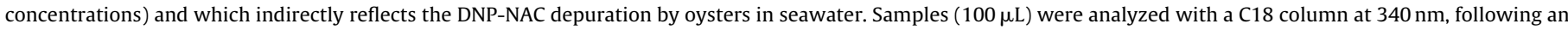

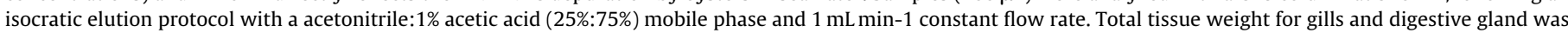

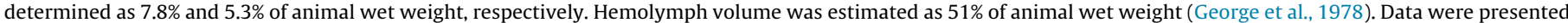
as average $+\operatorname{SEM}(n=3-6)$.

phase II metabolism was evident for gills (Fig. 3A), as the first MAP metabolite (DNP-SG) peaked at $15 \mathrm{~min}\left(203 \mathrm{nmol} \mathrm{g}^{-1}\right)$, and the intermediate metabolite DNP-CYS accumulated at $60 \mathrm{~min}$ $\left(308 \mathrm{nmol} \mathrm{g}^{-1}\right)$. This rapid metabolite buildup occurred simultaneously with the fast CDNB uptake in the first hours $\left(t_{1 / 2}=1.7 \mathrm{~h}\right)$. Both DNP-SG and DNP-CYS levels decreased close to zero by the end of exposure (24h). In the digestive gland (Fig. 3B), except for a DNPCYS peak at $4 \mathrm{~h}$ (153 nmol g), DNP-SG and DNP-CYS levels remained low throughout the 24 h exposure. In the hemolymph (Fig. 3C) DNPCYS peaked at $1 \mathrm{~h}(135 \mathrm{nmolg})$ and DNP-SG values were close to zero during all the exposure period. 
Table 2

Loss rate constants of mercapturic acid metabolites in 3 key tissues of the Pacific oyster Crassostrea gigas exposed to 1-chloro-2,4-dinitrobenzene (CDNB) for $24 \mathrm{~h}$

\begin{tabular}{llll}
\hline & DNP-SG $^{\mathrm{a}}$ & DNP-CYS $^{\mathrm{a}}$ & DNP-NAC $^{\mathrm{b}}$ \\
\hline Gills & $\begin{array}{l}0.32 \pm 0.09^{*} \\
\left(r^{2}=0.82\right)\end{array}$ & $\begin{array}{l}0.16 \pm 0.02^{* * *} \\
\left(r^{2}=0.93\right)\end{array}$ & $\begin{array}{l}0.54 \pm 0.10^{*} \\
\left(r^{2}=0.90\right)\end{array}$ \\
Digestive gland & $\begin{array}{l}0.19 \pm 0.05^{* *} \\
\left(r^{2}=0.89\right)\end{array}$ & N.D. & $\begin{array}{l}0.35 \pm 0.10^{*} \\
\left(r^{2}=0.80\right)\end{array}$ \\
Hemolymph & $\begin{array}{ll}0.46 \pm 0.17^{*} \\
\left(r^{2}=0.65\right)\end{array}$ & $\begin{array}{l}0.36 \pm 0.14^{*} \\
\left(r^{2}=0.60\right)\end{array}$ & N.D. \\
\hline
\end{tabular}

Data are expressed as $\mathrm{L} \mathrm{kg}^{-1} \mathrm{~h}^{-1}$ and mean \pm SD. N.D. stands for not determined

${ }^{a}$ single-component exponential model: $C_{t}=C_{0} \mathrm{e}^{-\mathrm{ket}}$.

${ }^{b}$ decreasing linear model: $C_{t}=\mathrm{a}-\left(\mathrm{k}_{\mathrm{e}} \mathrm{t}\right)$.

Probability $(\mathrm{p})$ of the parameter estimation:

${ }^{*}(p<0.05)$.

** $(p<0.01)$.

*** $(p<0.001)$

Interestingly, by calculating the absolute amount of DNP-SG and DNP-CYS metabolites (total nmol levels) accumulated in each tissue (based on average total tissue weight of gills and digestive gland or volume of hemolymph per animal), it was possible to identify different accumulation and metabolism patterns between tissues (Fig. 3D-F). Digestive gland, for instance, appears as a minor site for MAP to take place due to minor metabolite accumulation (Fig. 3E). On the other hand, gills were responsible for the major CDNBGSH conjugation, building up larger amounts of DNP-SG during the first hour, leading to the sequential MAP steps (Fig. 3D). Finally, hemolymph was shown to be an important reservoir and transport system for intermediate MAP metabolites, especially DNP-CYS (Fig. 3F). Overall, C. gigas accumulated approximately $2.5 \mu \mathrm{mol}$ DNP-SG + DNP-CYS metabolites in the gills, digestive gland and hemolymph (Fig. 3G) after $1 \mathrm{~h}$ of exposure to CDNB. Although this value is lower than the estimated CDNB accumulation for the first hour $(4.1 \mu \mathrm{mol})$, both numbers may be compatible as DNP-CG (another intermediate metabolite) could not be determined and other tissues were not investigated.

DNP-NAC, the final metabolite of the MAP, was detected in considerably lower levels in all tissues when compared to the other metabolites (Fig. 3A-C). It was observed, however, that DNP-NAC tended to accumulate in the hemolymph toward the end of exposure (Fig. $3 \mathrm{C}$ and F). By taking into account the MAP in mammals (Hinchman and Ballatori, 1994), one could infer that once DNP-CYS reaches the extracellular medium (and consequently hemolymph) it may be uptake by different oyster tissues and intracellularly acetylated, generating DNP-NAC for further excretion into seawater. Indeed, DNP-NAC was the most abundant of the three metabolites in the seawater (Fig. $3 \mathrm{H}$ ). The constant rate of DNP-NAC excretion from $C$. gigas to seawater was estimated as $0.15 \mathrm{~L} \mathrm{~kg}^{-1} \mathrm{~h}^{-1}$ (Fig. 3I), about 100-fold lower when compared to the fast uptake rate of CDNB. It is important to note that although DNP-NAC was the major metabolite detected in the seawater, other chromatogram peaks were detected at $340 \mathrm{~nm}$ in the seawater samples. Nevertheless, these additional peaks were not as intense as compared to the DNP-SG, DNP-CYS and DNP-NAC. In addition, we did not investigate other biotransformation pathways, such as glucuronidation and sulfation. Therefore, it is possible that CDNB metabolism may have been mediated by other metabolic pathways that were not taken into account in this study.

MAP metabolism in C. gigas was additionally assessed by biokinetic modeling of DNP-SG, DNP-CYS and DNP-NAC losses rates (transfer + metabolism). They were calculated for each tissue (Table 2) starting from the time point with the highest concentration of each compound (Fig. 3A-C), as follow: $15 \mathrm{~min}, 1 \mathrm{~h}$ and $4 \mathrm{~h}$ for DNP-SG in the gills, hemolymph and digestive gland, respectively; $1 \mathrm{~h}, 1 \mathrm{~h}$ and $4 \mathrm{~h}$ for DNP-CYS in the gills, hemolymph and digestive gland, respectively; and $10 \mathrm{~h}$ for DNP-NAC in all tissues. Interestingly, hemolymph presented the fastest loss rate for both DNP-SG and DNP-CYS, while DNP-NAC loss could not be calculated as it was accumulating in this tissue by the end of the exposure. Digestive gland presented the lowest loss rates for DNP-SG and DNP-NAC, with no significant modeling for DNP-CYS. Gills presented moderate and low loss rates for DNP-SG and DNP-CYS, respectively, probably due to the continuous synthesis of these metabolites in this tissue, while DNP-NAC loss rate was the highest among the analyzed tissues.

Phase II metabolism was also assessed in the gills and digestive gland using an in vitro experiment. Incubation of these tissues extracts with GSH and CDNB for detection of DNP-SG synthesis revealed that gills present a higher CDNB-GSH conjugation rate, synthetizing DNP-SG 2.2 times faster than digestive gland (Supplementary Fig. 3). Another experiment was carried out with tissue extracts incubated with DNP-SG, and further DNP-SG levels analysis revealed that this metabolite half-life was $2.7 \mathrm{~h}$ for digestive gland versus $5.8 \mathrm{~h}$ for gills (Supplementary Fig. 3). Data indicate that digestive gland has a faster DNP-SG-dependent $\gamma$-glutamyl transpeptidase rate than gills in an ex vivo context.

\subsection{Antioxidant impairment and upregulation of phase II biotransformation}

Modulation of GSH levels and activity of antioxidant and biotransformation-related enzymes were also investigated in both gills and digestive gland, which were hypothesized to be affected by CDNB. As expected, CDNB exposure altered GSH levels in the gills (Fig. 4A), which exhibit a $61 \%$ consumption after $4 \mathrm{~h}$ and $97 \%$ consumption after $24 \mathrm{~h}$. Decreased GR (Fig. 4C) and TrxR (Fig. 4E) activities were also detected in this tissue after CDNB exposure: approximately $60 \%$ decrease after 10 and $24 \mathrm{~h}$ for $\mathrm{GR}$, and $50 \%$ after $4 \mathrm{~h}$ for TrxR. In addition, $75 \%$ increase in GST activity was detected in the gills after $24 \mathrm{~h}$ exposure (Fig. 4G). In contrast these parameters were not affected in the digestive gland (Fig. 4), except for a $35 \%$ decrease in GST activity after $24 \mathrm{~h}$ (Fig. 4H). GGT activity (an enzyme participating in the MAP) was not affected by the CDNB exposure in both tissues (data not shown).

The increased GST activity observed in the gills could be related to an increased expression of phase II biotransformation genes. Therefore, transcript levels of three different GST isoforms (GSTo, GSTpi and GSTmu) as well as the rate-limiting enzyme for GSH synthesis (GCL) were assessed in the gills and digestive gland of oysters exposed to CDNB. In accordance with the increased GST activity, after $4 \mathrm{~h}$ of exposure the transcript levels of GSTo and GSTpi were approximately 73-fold and 6.6-fold higher than control levels, respectively, and quickly returned to basal levels after $10 \mathrm{~h}$ (Fig. $5 \mathrm{~A}$ and B). GSTmu transcript levels remained unaltered in all exposure periods (data not shown). In contrast, in the digestive gland, while GSTo and GSTmu transcript levels remained unchanged, GSTpi mRNA levels presented a 2.7-fold and 1.2-fold decrease after 10 and $24 \mathrm{~h}$, respectively (Supplementary Fig. 4). In the gills GCL mRNA levels were also modulated by CDNB exposure, exhibiting a 6.5-fold increase after $4 \mathrm{~h}$ (Fig. 5C).

\subsection{Role of gills on protecting against waterborne electrophilic agents}

To further investigate this role of gills in phase II biotransformation, which appear as an example of metabolic barrier against waterborne electrophilic agents, CDNB was administered intramuscularly. This approach was used to allow the compound to immediately reach hemolymph and other tissues, preventing the initial and intense CDNB-GSH conjugation step in the gills. Following previous results (Fig. 4), GSH, GST, GR and TrxR were analyzed as 

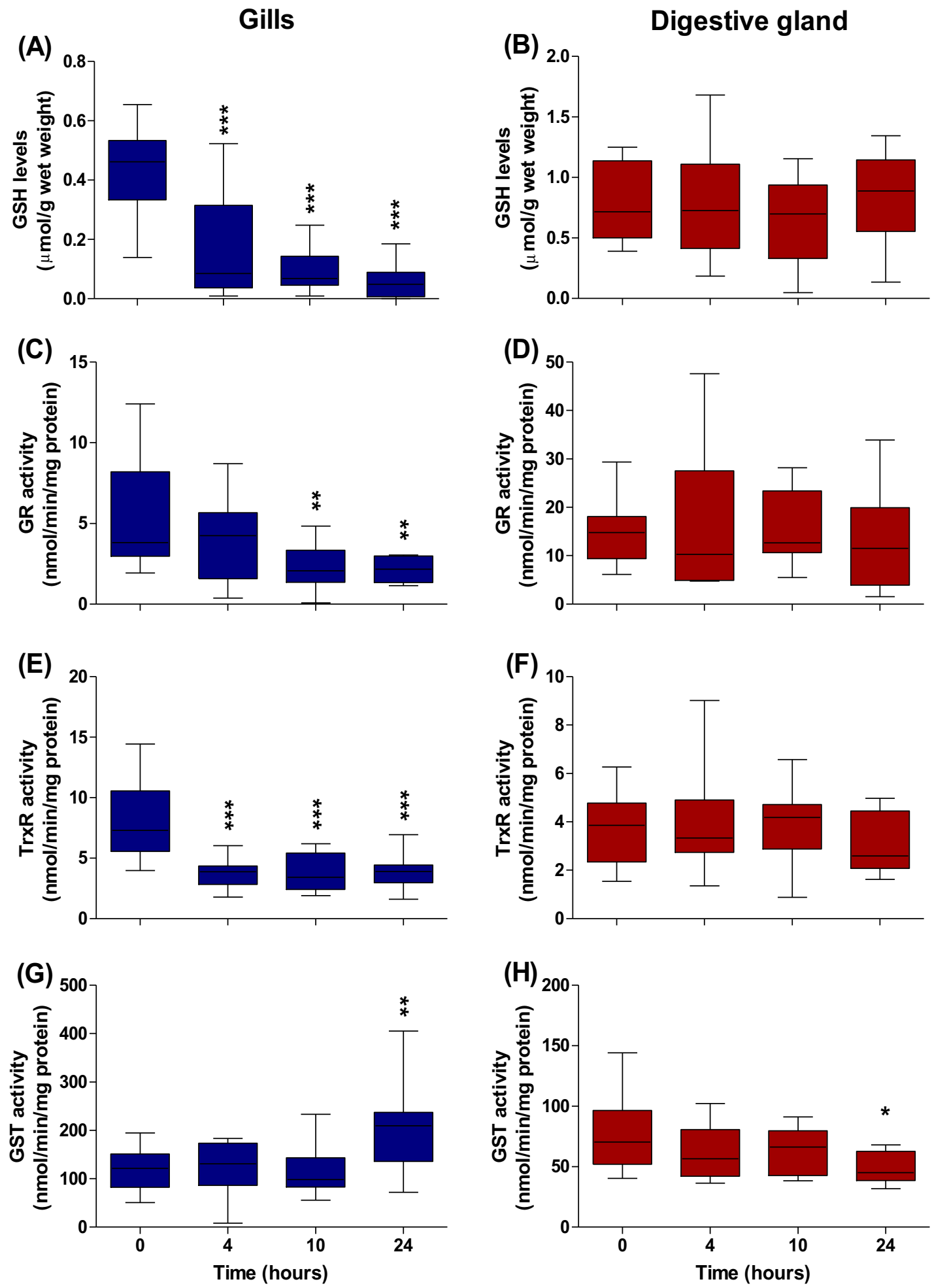

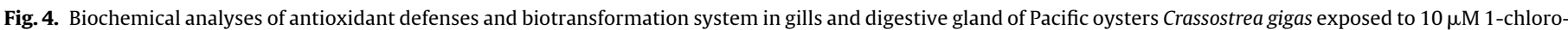

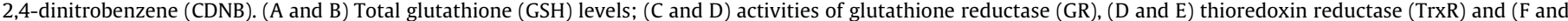

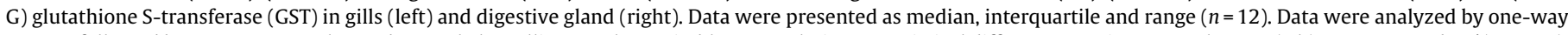

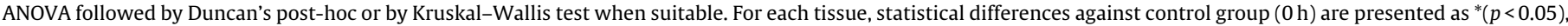
${ }^{* *}(p<0.01)$ and ${ }^{* * *}(p<0.001)$.

markers of CDNB exposure after $24 \mathrm{~h}$ (Fig. 6). In the gills, lower GSH levels (30\%), increased GST activity (42\%) and decreased GR activity (52\%) were observed at the highest dose (Fig. 6A, C and E) while TrxR remained unchanged. In the digestive gland, the only parameter affected was GR activity, with $39 \%$ decrease at the $3 \mu \mathrm{mol}$ dose
(Fig. 6F), pointing to a low CDNB bioavailability to this tissue as compared to gills.

The hypothesis of gills acting as primary site for biotransformation of electrophilic substances was further investigated by exposing oysters to the cell-permeable and thiol depleting agent 

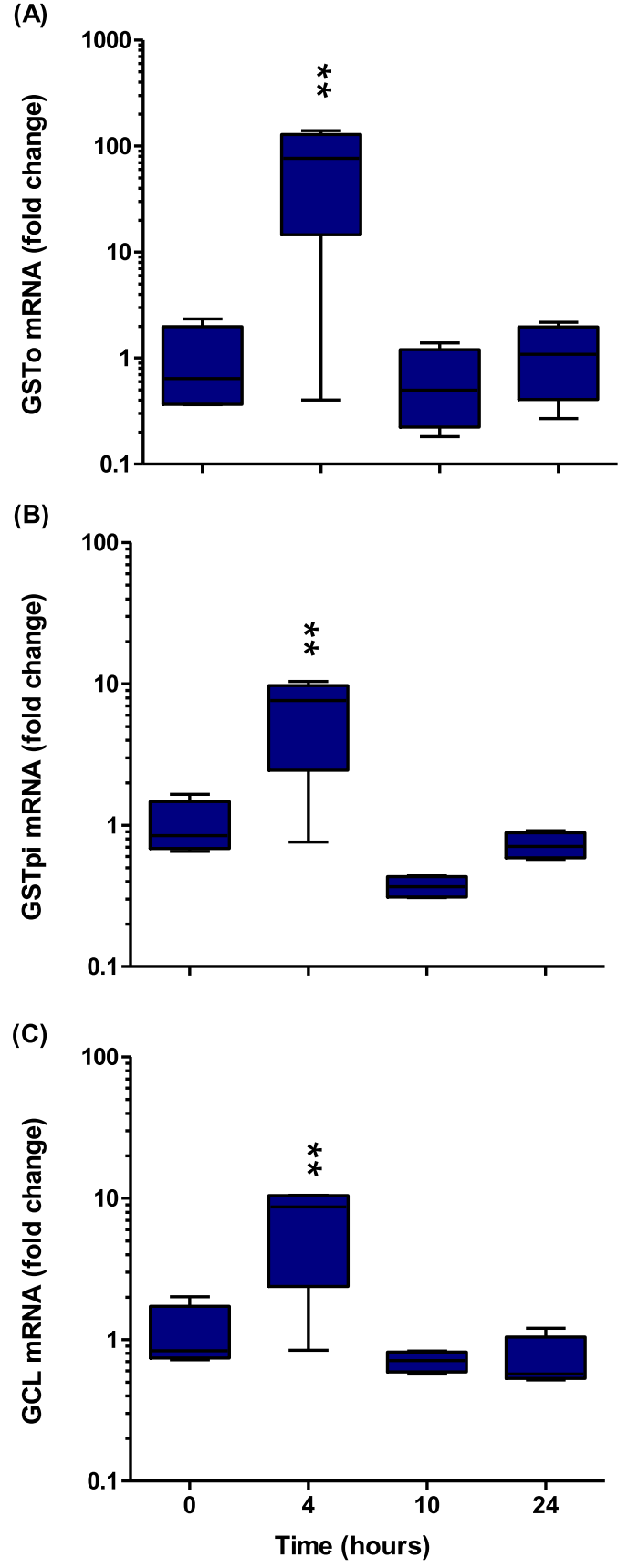

Fig. 5. Transcript levels of glutathione S-transferase (GST) and glutamate-cysteine ligase (GCL) transcription in gills of Pacific oysters Crassostrea gigas exposed to $10 \mu \mathrm{M}$ 1-chloro-2,4-dinitrobenzene (CDNB). (A) GST isoforms omega (GSTo), (B) pi (GSTpi) and (C) GCL Data are presented as median, interquartile and range $(n=4)$, with the fold induction expressed in logarithmic scale. Data were analyzed by one-way ANOVA followed by Duncan's post-hoc when suitable. For each tissue, statistical differences against control group are presented as $* *(p<0.01)$.

NEM. Due to its alkylating effect, NEM is expected to deplete thiols from proteins and low molecular weight molecules, such as GSH. Similarly to CDNB, oysters were waterborne $(1-1000 \mu \mathrm{M})$ or intramuscularly (10-300 $\mu \mathrm{mol}_{\text {organism }}{ }^{-1}$ ) exposed to NEM, and GSH content was determined in the gills and digestive gland after $1 \mathrm{~h}$ of exposure. In accordance with the results obtained with CDNB, there were clear distinctive patterns of GSH depletion, depending on the exposure mode. Waterborne NEM caused GSH consumption in the gills (67-82\%, Fig. 7A) but not in the digestive gland (Fig. 7B), while intramuscular NEM depleted almost all GSH in both tissues (up to $98 \%$, Fig. 7C and D).

Average values of GSH depletion were further used to estimate the $50 \%$ inhibitory concentration $\left(\mathrm{IC}_{50}\right)$ of waterborne and intramuscular NEM. Waterborne NEM exposure presented an $\mathrm{IC}_{50}$ value 8 times lower for gills ( $32 \mu \mathrm{M})$, as compared to the digestive gland $(269 \mu \mathrm{M})$. This difference was even more preeminent when NEM was administered intramuscularly, presenting a 50 times lower $\mathrm{IC}_{50}$ value for gills $(3.2 \mu \mathrm{M})$ when compared to digestive gland $(162 \mu \mathrm{M})$. These results clearly show that NEM was much more effective in reacting with thiols present in the gills, as compared to the digestive gland.

\section{Discussion}

\subsection{CDNB fate in Pacific oysters C. gigas}

We investigated the MAP in oysters $C$. gigas, an important yet poorly studied biotransformation pathway in bivalves. Chemical analyses of CDNB and MAP metabolites were performed during an acute waterborne exposure to the model electrophile CDNB, and data were integrated in biokinetic modeling. In summary, data strongly suggest (i) the existence of a complete MAP pathway in $C$. gigas, (ii) the pivotal role of gills on the GSH-dependent metabolism of electrophiles, and (iii) the seawater as a sink for the final MAP metabolite under the employed exposure conditions.

The MAP is a well-known cellular defense pathway, composed by several enzymatic steps and cellular transport events. In mammals, MAP metabolites are exported out of the cell by specific transporters and distributed to other tissues by the circulatory system, allowing the participation of other organs (Hinchman and Ballatori, 1994). The liver acts as an important site for CDNB conjugation with GSH given its higher GST activity, while kidneys act on the biotransformation of DNP-SG, generating DNP-CYS due to its higher ectopeptidase activity. DNP-CYS is further imported by liver or kidneys, and the final MAP product (DNP-NAC) is generated intracellularly by $\mathrm{N}$-acetylation, before it can be further excreted. Intestine may also synthetize DNP-SG and DNP-CYS for further $\mathrm{N}$-acetylation. Mercapturic acids, the $\mathrm{N}$-acetylated cysteine conjugates, can be excreted via bile or urine. In bivalves, the detailed metabolic organization of the MAP still needs investigation, nonetheless our data point to some similarities with mammals in a model of acute exposure to waterborne electrophiles: an important site for DNP-SG formation was detected (gills), and the circulatory system (hemolymph) permitted an interorgan metabolism. Likewise, other organs (e.g., digestive gland) may also play a role in the MAP in bivalves. Overall, each of the studied tissues (gills, digestive gland and hemolymph) revealed different uptake, bioconcentration and excretion rates for CDNB metabolites, suggesting differential roles.

\subsubsection{Absorption and GSH conjugation}

According to biokinetic modeling, CDNB bioconcentration should be evident, due to its fast disappearance in the seawater (half-life of $1.7 \mathrm{~h}$ ). However, CDNB was not detected in the tissues analyzed in this study (bellow detection limit), probably due to the high biotransformation via GSH-conjugation as soon as it is taken up by gills and other tissues. Indeed, GSH depletion occurred in parallel to a fast and robust DNP-SG build up ( $15 \mathrm{~min})$ in the gills and the CDNB disappearance from the seawater. In turn, the DNP-SG bioaccumulation probably occurs because the loss rate was at least 2 orders of magnitude slower in all tissues than the CDNB uptake rate from seawater, which partially reflects the DNP-SG formation rate. 


\section{Gills}

(A)

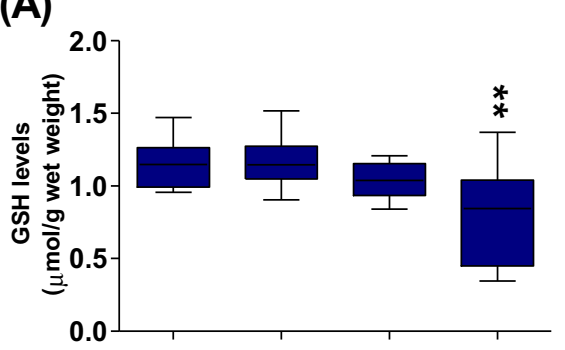

(C)

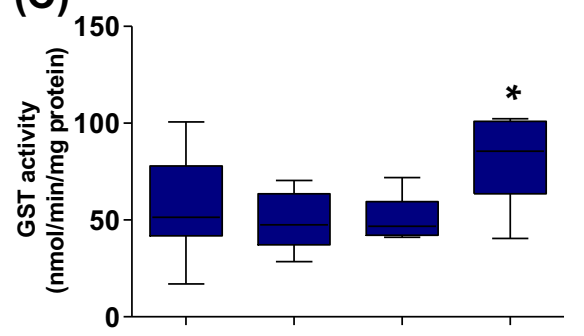

(E)

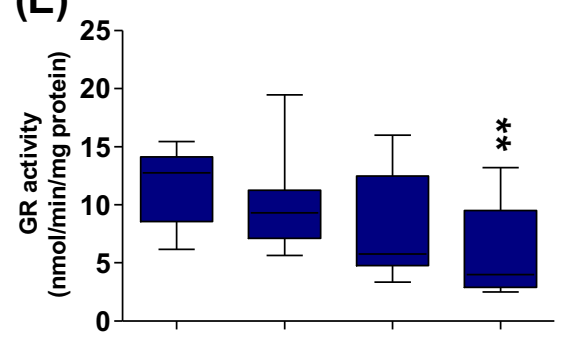

(G)

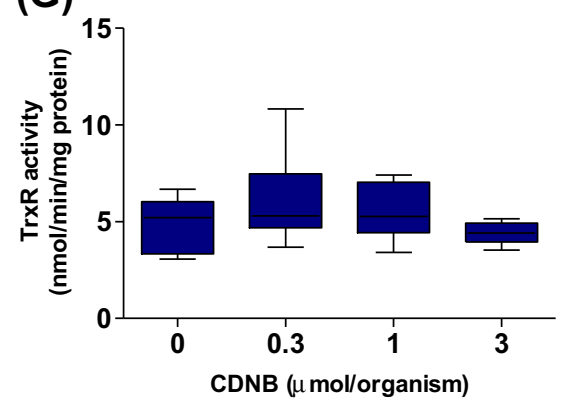

Digestive gland

(B)

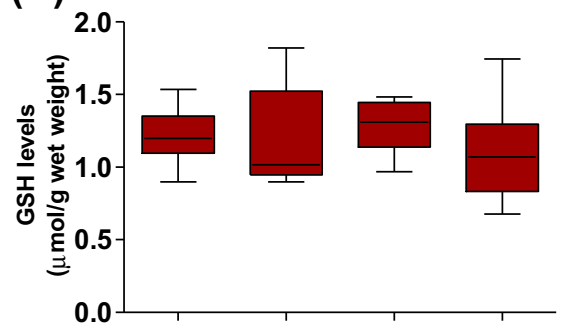

(D)

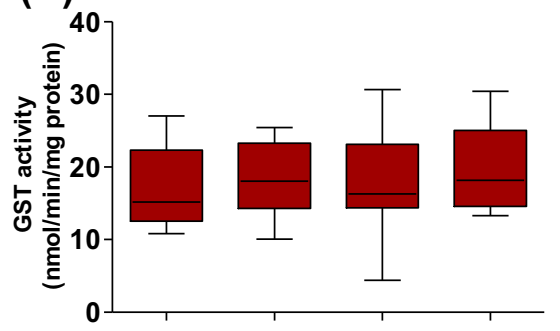

(F)

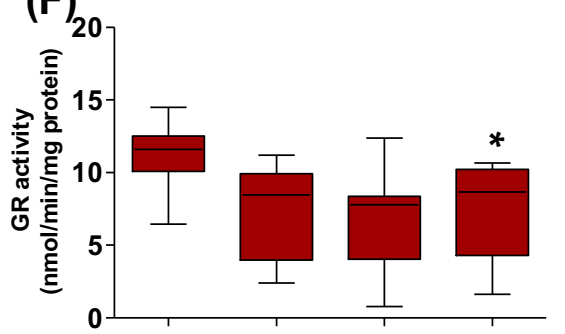

(H)

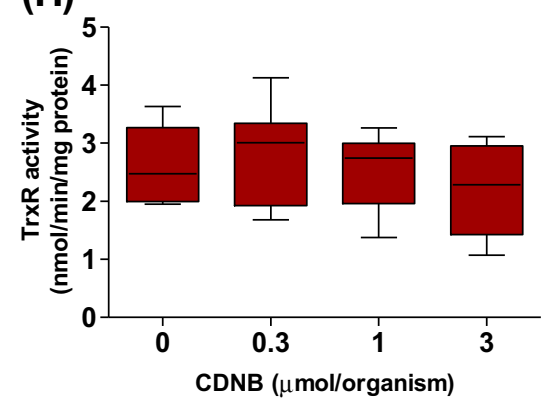

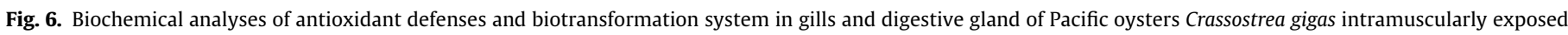

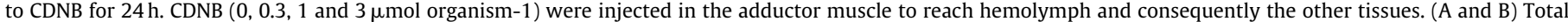

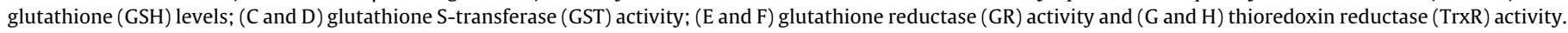

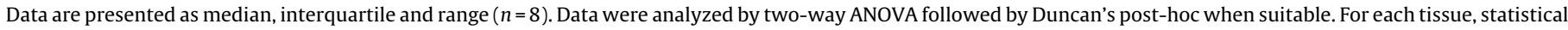
differences against control group $(0 \mu \mathrm{mol})$ are presented as ${ }^{*}(p<0.05)$ and ${ }^{* *}(p<0.01)$.

DNP-SG loss rate was similar between studied tissues; however, absolute and relative levels of this metabolite were expressively lower in the digestive gland and hemolymph, when compared to gills.

Besides DNP-SG formation, other markers related to GSH conjugation were evaluated in this study. Rapid $(4 \mathrm{~h})$ increase in mRNA levels related to the enzyme responsible for the rate-limiting step in GSH synthesis (GCL, Lu, 2013) was observed. This event was accompanied by the upregulation of two GST transcripts (GSTo and GSTpi, $4 \mathrm{~h}$ ), followed by an increase in GST activity ( $24 \mathrm{~h}$ ) in the gills. Both GSTo and GSTpi have known conjugating activity toward CDNB (Hayes and Strange, 2000), probably contributing to the increased GST activity observed in gills. These data are in line with the idea of a counteracting mechanism to maintain CDNB conjugation and GSH supply, especially in the gills.
Altogether, biokinetic modeling, molecular and biochemical analyses are in line with the idea that gills are a quick-responding organ and an important site for GSH-conjugation of electrophilic substances in oysters $C$. gigas under acute waterborne exposure, providing substrates for the following steps in the MAP.

\subsubsection{Metabolism and excretion}

In the next MAP step, according to mammalian metabolism, DNP-SG is transported out of the cell with the help of ABCC proteins, and further metabolized by extracellular peptidases (Hinchman and Ballatori, 1994). Studies suggest an important role for ABCC proteins in mollusks, protecting these animals against the chemical burden and toxicity of pollutants or toxic substances obtained from the diet (Luckenbach et al., 2008; Navarro et al., 2012; Whalen et al., 2010). As transporters of GSH-conjugates, the cellular protec- 
(A)

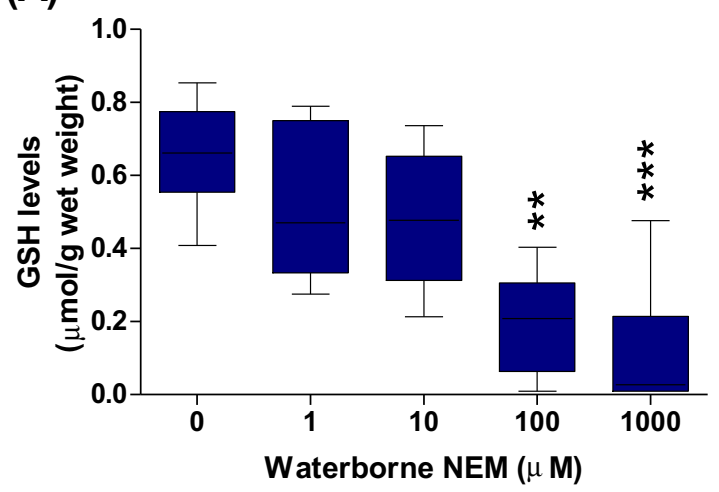

(C)

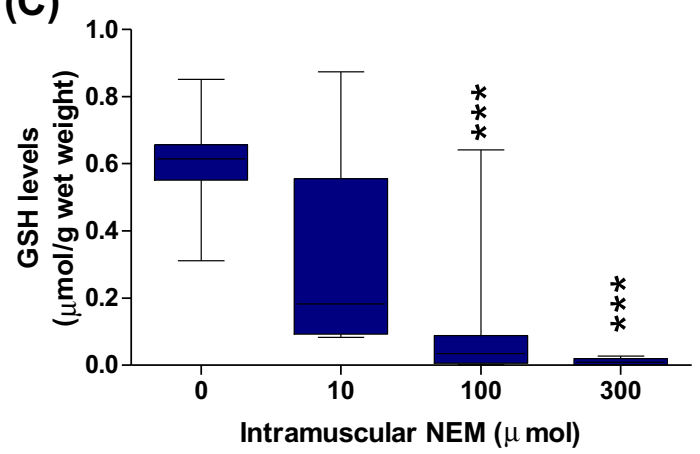

(B)
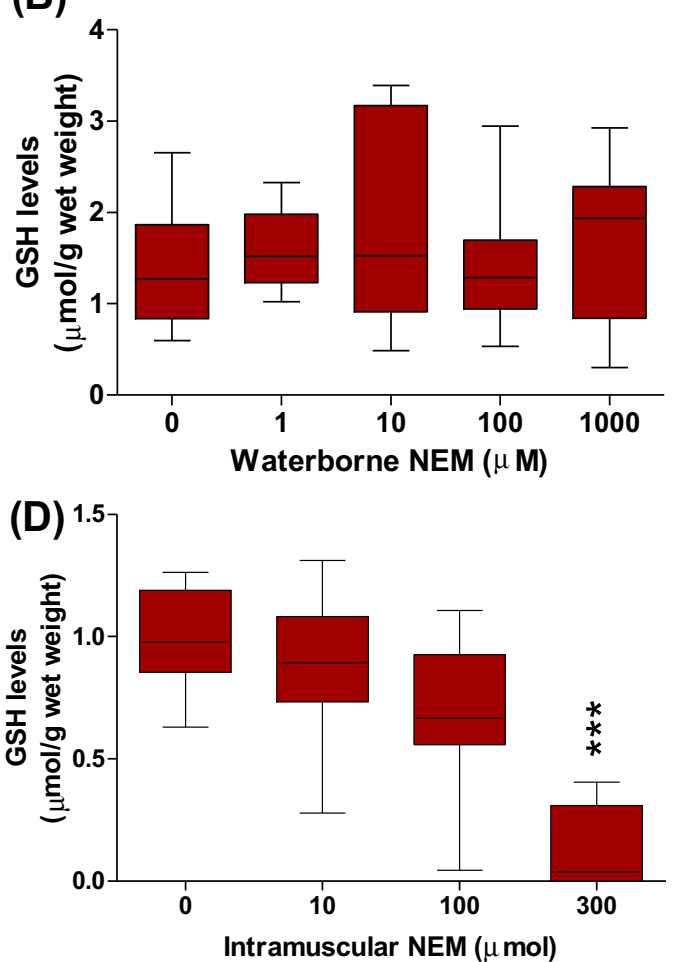

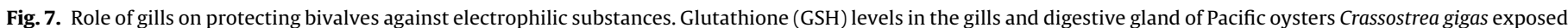

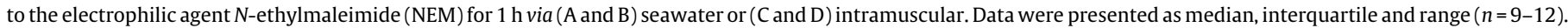

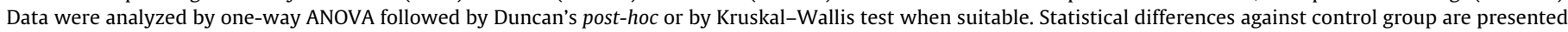
as ${ }^{* *}(p<0.01)$ and ${ }^{* * *}(p<0.001)$.

tion granted by ABCCs proteins may be linked to the action of the MAP in invertebrate aquatic species.

Once in the extracellular environment, DNP-SG can be further metabolized by peptidases, releasing glutamate and glycine residues and originating DNP-CYS (Hinchman and Ballatori, 1994). DNP-CYS build up was most preeminent in the gills when compared to other tissues, occurring as rapid and intense as DNP-SG. Absolute DNP-CYS burden revealed, however, that hemolymph was a major site for DNP-CYS bioaccumulation, supporting a role in DNP-CYS transport. If we use an analogy to the mammalian MAP, the open circulatory system of bivalves may facilitate the action of ectopeptidases on DNP-SG at different sites. However, GGT activity is one order of magnitude higher in the digestive gland than in the

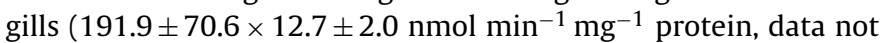
shown). Digestive gland also presented a higher in vitro DNP-SG degradation rate, but DNP-CYS absolute levels were extremely low in this tissue at most time periods, pointing to a minor action of GGT from the digestive gland during biotransformation of waterborne CDNB. On the other hand, data suggest that the notable GGT activity in the digestive gland may favor DNP-CYS formation in a scenario presenting higher availability of CDNB and DNP-SG for this organ, which was not supported by the data obtained in this study. However, this could be the case for prolonged or dietary exposures to CDNB or other electrophilic substances. It is plausible to assume that the digestive gland would have a much more important role in the presence of electrophilic metabolites derived from oxidative stress and from the phase I of biotransformation, given that this organ has high phase I activity (Livingstone and Farrar, 1984; Solé and Livingstone, 2005) and abundance of MAP enzymes, as suggested by data shown in Section 3.

After DNP-CYS burden ceased (1-4h), hemolymph presented a high loss rate, suggesting that other tissues incorporate this metabolite. In such tissues, DNP-CYS can be further $N$-acetylated to generate DNP-NAC, the final MAP product. The highest levels of DNP-NAC were observed in the hemolymph, as compared to gills and digestive gland, and by far the most abundant metabolite in the seawater. One hypothesis congregating these findings is that tissues without direct contact with seawater would release DNPNAC to hemolymph, which would be further transported to other tissues such as gills and finally excreted to seawater.

\subsection{Gills as an effective GSH-dependent metabolic barrier against electrophilic substances}

Gills are considered the main absorption route of waterborne chemical compounds in aquatic organisms, especially due to the wide contact with seawater and a high exchange rate of solutes between gills and blood/hemolymph (Hayton and Barron, 1990). This process begins when water-soluble compounds are brought close to the surface of gills along with the water flow produced by ciliated cells. These compounds can subsequently diffuse or be transported through the gill's epithelium to the circulatory system and be further distributed across the organism (Erickson and McKim, 1990). Taking this process into account, it is reasonable to expect that this organ would have high defense ability against contaminants. Indeed, it has already been suggested that gills of bivalves can be an environment-tissue barrier through the action of ABC transporters (Luckenbach and Epel, 2008), although this hypothesis did not encompass phase II biotransformation events, such as the MAP. Other studies are in conformity with the idea that gills are a major site for entrance of contaminants, where the modulation of important cellular defense systems takes place, such as induction of biotransformation and antioxidant-related enzymes, and metallothioneins (Ahmad et al., 2011; Bebianno et al., 2004; 


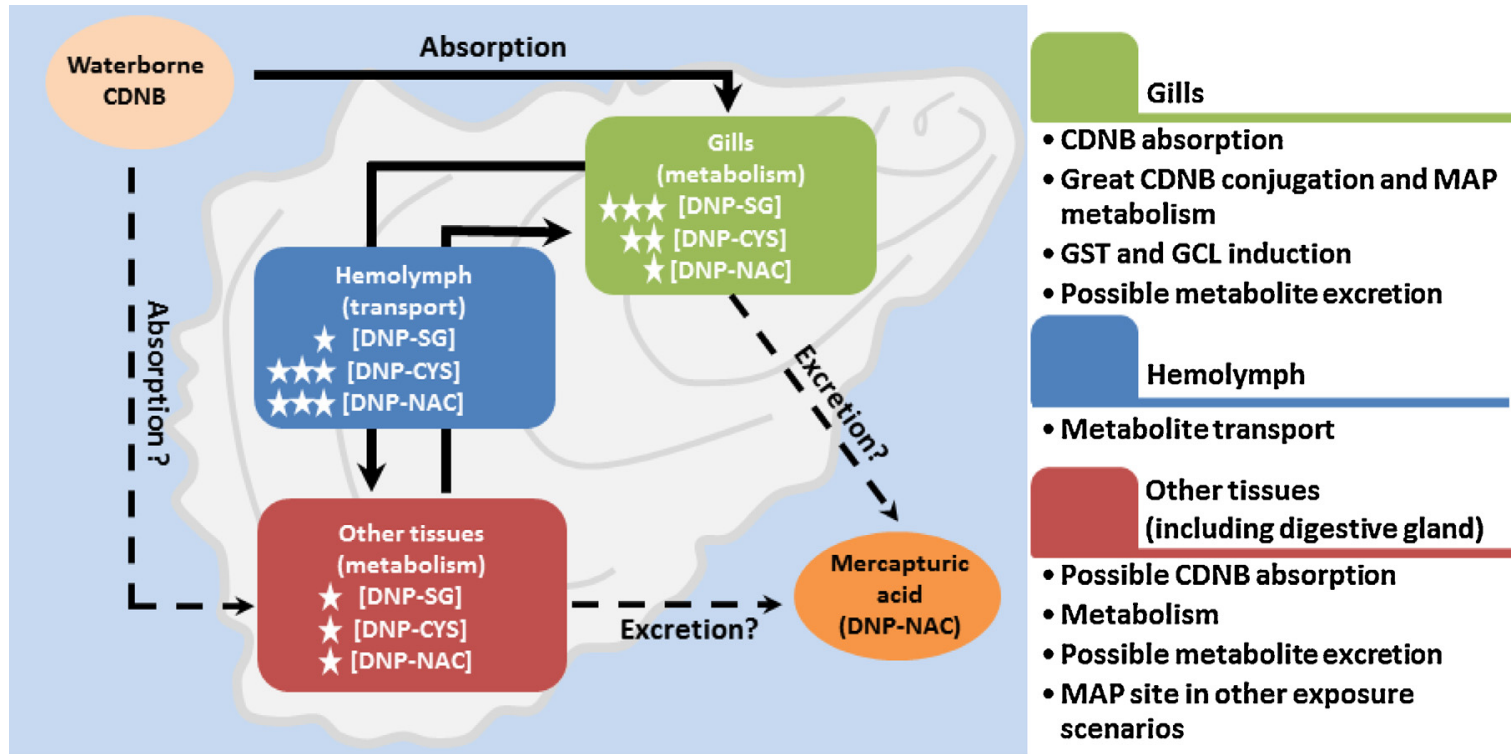

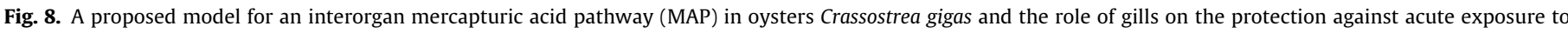

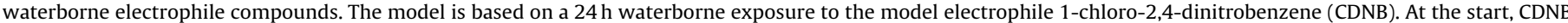

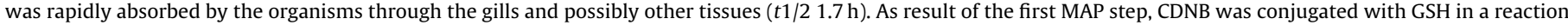

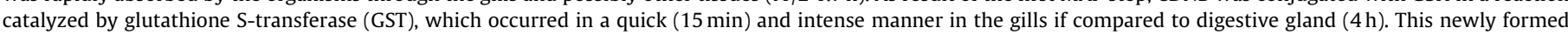

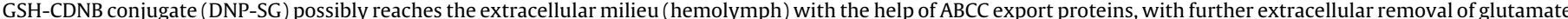

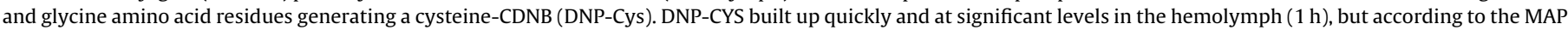

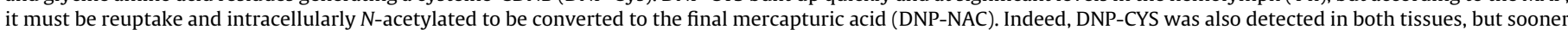

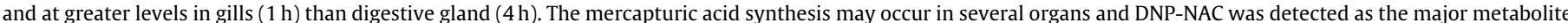

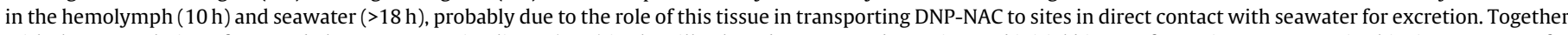

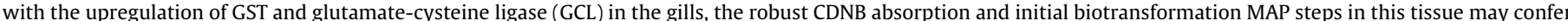

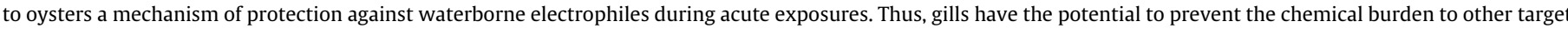

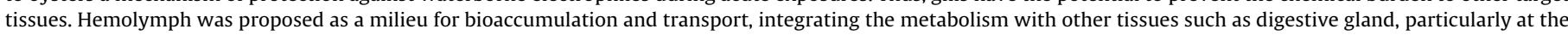

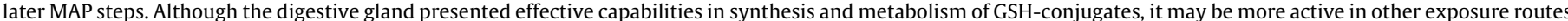
and scenarios. Relative concentrations of each CDNB metabolite in tissues are indicated as one (low), two (moderate) or three stars (high).

Châtel et al., 2012; Géret et al., 2002; Lüchmann et al., 2014, 2011; Maria et al., 2009; Trevisan et al., 2014b; Zanette et al., 2008). The data from this study reinforce the idea of a central role of gills in scenarios of acute exposure to waterborne electrophiles, by integrating absorption, metabolism and excretion of CDNB through the MAP. CDNB leads to pronounced GSH consumption in the gills, which was accompanied by upregulation of the gene responsible for the first and limiting step in GSH synthesis (GCL) and two GST isoforms, which would favor the bioaccumulation of initial MAP metabolites in the gills. These previous studies, along with ours, support the idea of gills as a key player in organismal defense, acting as an effective GSH-dependent metabolic barrier, and together with the hemolymph, digestive gland and other tissues, assisting the organism to integrate absorption, metabolism and excretion of electrophilic contaminants.

\subsubsection{GSH-related parameters and GSTs}

Increased GST activity occurred only in the gills at $24 \mathrm{~h}$, probably due to an efficient induction of GST genes, as shown for GSTo, and GSTpi at $4 \mathrm{~h}$ post-exposure to CDNB. Interestingly, RNA transcript levels in the digestive gland remained stable or even decreased for the same GST isoforms.

As aforementioned, GST is a family of proteins responsible for conjugating electrophilic compounds with GSH (Board and Menon, 2013), thus it is expected a marked GSH decrease when this process is taking place in an intense manner. In accordance, our results indicated once more that GSH depletion was observed in the gills, but not in the digestive gland. Furthermore, increased GCL transcription was observed in the gills, which may be an adaptive response to provide additional GSH to support CDNB conjugation
(Ghersi-Egea et al., 2006), along with protection against oxidative stress (Lu, 2013). GSH-synthesis after the GSH depletion caused by CDNB exposure has already been reported in vitro in skin cells (Jacquoilleot et al., 2015) and in vivo in the gills of $C$. gigas (Trevisan et al., 2012).

\subsubsection{Antioxidant enzymes}

Evidences that reinforce the idea of gills as a metabolic barrier, lowering chemical burden in other tissues, include the decreased GR and TrxR activity in the gills. Inhibition of TrxR (Heiss and Gerhäuser, 2005; Seyfried and Wüllner, 2007) and GR (Bilzer et al., 1984) by CDNB or DNP-SG was demonstrated in mammals. Impaired GR and TRxR activity, along with GSH depletion has already been reported in vivo in oysters and mussels (Trevisan et al., 2014c, 2012), as well as in vitro in hemocytes from oysters (Mello et al., 2015).

Impairment of thiol reductases in bivalve gills have been associated with the toxic effect of different compounds, including pharmaceuticals (Brandão et al., 2014; Gonzalez-Rey and Bebianno, 2011), nanomaterials (Trevisan et al., 2014a), metals (MacíasMayorga et al., 2015) and redox-cycling quinones (Tedesco et al., 2010). In addition, impairment of the gills glutathione peroxidase system (through GSH depletion and GR inhibition) was already reported to decrease in vivo peroxide detoxification rate and animal survival when exposed to oxidants (Trevisan et al., 2014c, 2012) Likewise, amplification of glutathione-related defenses in the gills can also protect against oxidative stress-mediated toxicity of metals, as already suggested in blue mussels (Trevisan et al., 2011). These results suggest that gills antioxidant defenses, including the 
GSH-related system, may be associated to oyster susceptibility to pro-oxidants agents.

\subsubsection{Waterborne vs. intramuscular electrophilic insults}

With the use of an acute ( $24 \mathrm{~h}$ ) waterborne exposure to CDNB, gills were characterized as an important GSH-dependent metabolic barrier to bivalves, preventing the bioaccumulation of electrophilic compounds to other tissues in such conditions. The use of an intramuscular exposure to CDNB or NEM, by direct injection into the adductor muscle, would allow these electrophiles to reach the circulatory system, circumventing the putative metabolic barrier provided by the gills.

Intramuscular injected CDNB caused marked effects on gills (GSH consumption, GR inhibition and GST induction), and also affected digestive gland through GR inhibition, which was not observed with waterborne exposure. NEM is a water soluble and membrane permeable thiol alkylating agent (Haj-Yehia and Benet, 1996; Morré and Morré, 1995; Murphy et al., 1992), which is expected to rapidly deplete GSH. As expected, GSH was consumed in the gills during waterborne NEM exposure, while in the digestive gland GSH was only affected by intramuscular injection, a pattern similar to that observed with CDNB. Moreover, by comparing the $\mathrm{IC}_{50}$ of NEM toward GSH levels, it is clear that gills are much more susceptible to both waterborne and intramuscularexposure to thiol-alkylating agents, as it was 8 and 50 times lower than digestive gland, respectively. Altogether, these data suggest that gills are an effective GSH-metabolic barrier against waterborne electrophiles, which, according to our data, still holds true when metabolites gain access to the circulatory system. However, these data also indicate that digestive gland does have an effective GSHconjugating capability, and together with the higher GGT activity detected in this tissue, open the possibility that digestive gland may be a major site for MAP in other exposure scenarios, especially in long-term or diet exposures.

\section{Conclusions}

This study is the first preliminary description of the MAP in bivalves, using CDNB as model compound and an acute waterborne exposure (Fig. 8). Data suggest that under the proposed exposure condition the MAP is an important mechanism of cellular defense with the coordinated action of gills, hemolymph and digestive gland (i) gills appear as an initial site where the first MAP steps take place, with especial attention to the preeminent GSH-conjugation capability of this tissue; (ii) hemolymph transports metabolites throughout the organism, especially DNP-CYS and DNP-NAC; (iii) the digestive gland and possibly other tissues may assist on CDNB absorption and metabolism; and lastly (iv) the final mercapturic acid metabolite (DNP-NAC) excretion could be followed in the seawater, although it was not possible to identify the route of excretion. In addition, ( $v$ ) gills exhibited a robust detoxification system, with rapid amplification of key proteins and genes related to the phase II biotransformation. Despite the fact that this study was limited to an acute waterborne exposure of a model electrophile, hindering definitive conclusions, it is proposed that gills are an example of a remarkable GSH/GST-dependent detoxifying organ in bivalves, a role that remains open to other tissues and which can be investigated in future studies.

\section{Disclosure}

All authors declare to have no actual or potential conflict of interest including financial, personal or other relationships with other people or organizations. The work described has not been published previously (except in the form of an abstract or thesis); it is not under consideration for publication elsewhere; and its publication is approved by all authors and tacitly or explicitly by the responsible authorities where the work was carried out, and if accepted, it will not be published elsewhere in the same form, in English or any other language, without the consent of the copyright holder. The authors also declare that all experiments were carried out according to the local Research Ethics Committee at Federal University of Santa Catarina.

All authors declare to have participated in this study, as following: experimental design, RT and ALD; methodological protocols RT, DFM, NMD, DGHS, MM, EAA and ALD; CDNB and metabolites chemical analysis: RT, DGHS and EAA; biokinetic modeling: MM; qPCR assays: RT, DFM and NMD; biochemical assays: RT, GD and MA; data analysis and article preparation: all authors.

\section{Acknowledgments}

R.T., D.F.M. and N.M.D. were recipient of scholarships awarded by the Coordination of Improvement of Higher Education Personnel (CAPES). We are thankful to the LAMEB and LIAA laboratories (UFSC) for the technical assistance and to Dr. Diego R. Barnache for kindly revising the manuscript. We would like to acknowledge research grants provided by the Brazilian National Development and Research Council (CNPq)-Instituto Nacional de Ciência e Tecnologia de Toxicologia Aquática (INCT-TA), Brasília, DF, Brazil (\# 573949/2008-5) and CNPq (\# 462333/2014-0 and \# 406426/2012$0)$. The IAEA is grateful for the support provided to its Environment Laboratories by the Government of the Principality of Monaco. A.L.D and E.A.A. are research fellows of CNPq.

\section{Appendix A. Supplementary data}

Supplementary data associated with this article can be found, in the online version, at http://dx.doi.org/10.1016/j.aquatox.2016.01. 008 .

\section{References}

Abraham, A., Wang, Y., El Said, K.R., Plakas, S.M., 2012. Characterization of brevetoxin metabolism in Karenia brevis bloom-exposed clams (Mercenaria sp.) by LC-MS/MS. Toxicon 60, 1030-1040, http://dx.doi.org/10.1016/j.toxicon. 2012.06.016.

Ahmad, I., Mohmood, I., Mieiro, C.L., Coelho, J.P., Pacheco, M., Santos, M.A., Duarte, A.C., Pereira, E., 2011. Lipid peroxidation vs. antioxidant modulation in the bivalve Scrobicularia plana in response to environmental mercury-organ specificities and age effect. Aquat. Toxicol. 103, 150-158, http://dx.doi.org/10 1016/j.aquatox.2011.02.017.

Akerboom, T.P., Sies, H., 1981. Assay of glutathione, glutathione disulfide, and glutathione mixed disulfides in biological samples. Methods Enzymol. 77 373-382.

Aloıísio Torres, M., Pires Testa, C., Gáspari, C., Beatriz Masutti, M., Maria Neves Panitz, C., Curi-Pedrosa, R., Alves de Almeida, E., Di Mascio, P., Wilhelm Filho, D., 2002. Oxidative stress in the mussel Mytella guyanensis from polluted mangroves on Santa Catarina Island, Brazil. Mar. Pollut. Bull. 44, 923-932, http://dx.doi.org/10.1016/S0025-326X(02)00142-X.

Apeti, D.A., Lauenstein, G.G., Christensen, J.D., Kimbrough, K., Johnson, W.E. Kennedy, M., Grant, K.G., 2010. A historical assessment of coastal contamination in Birch Harbor, Maine based on the analysis of mussels collected in the 1940 and the Mussel Watch Program. Mar. Pollut. Bull. 60, 732-742, http://dx.doi.org/10.1016/j.marpolbul.2009.11.021.

Arnér, E.S., Zhong, L., Holmgren, A., 1999. Preparation and assay of mammalian thioredoxin and thioredoxin reductase. Methods Enzymol. 300, 226-239.

Bebianno, M.J., Géret, F., Hoarau, P., Serafim, M.A., Coelho, M.R., Gnassia-barelli, M., Roméo, M., 2004. Biomarkers in Ruditapes decussatus: a potential bioindicator species. Biomarkers 9, 305-330, http://dx.doi.org/10.1080/ 13547500400017820.

Bilzer, M., Krauth-Siegel, R.L., Schirmer, R.H., Akerboom, T.P.M., Sies, H., Schulz, G.E., 1984. Interaction of a glutathione S-conjugate with glutathione reductase. Kinetic and X-ray crystallographic studies. Eur. J. Biochem. 138, 373-378, http://dx.doi.org/10.1111/j.1432-1033.1984.tb07925.x.

Blanchette, B.N., Singh, B.R., 2003. An enzyme based dechlorination of a polychlorinated biphenyl (PCB) mixture, Aroclor 1248, using glutathione S-transferases from the northern quahog Mercenaria mercenaria. J. Protein Chem. 22, 377-386. 
Board, P.G., Menon, D., 2013. Glutathione transferases, regulators of cellular metabolism and physiology. Biochim. Biophys. Acta 1830, 3267-3288, http:// dx.doi.org/10.1016/j.bbagen.2012.11.019.

Borković, S.S., Šaponjić, J.S., Pavlović, S.Z., Blagojević, D.P., Milošević, S.M. Kovačević, T.B., Radojičić, R.M., Spasić, M.B., Žikić, R.V., Saičić, Z.S., 2005. The activity of antioxidant defence enzymes in the mussel Mytilus galloprovincialis from the Adriatic Sea. Comp. Biochem. Physiol. C 141, 366-374, http://dx.doi. org/10.1016/j.cbpc.2005.08.001.

Boyland, E., Chasseaud, L.F., 1969. The role of glutathione and glutathione S-transferases in mercapturic acid biosynthesis. Adv. Enzymol. Relat. Areas Mol. Biol. 32, 173-219.

Bradford, M.M., 1976. A rapid and sensitive method for the quantitation of microgram quantities of protein utilizing the principle of protein-dye binding. Anal. Biochem. 72, 248-254.

Brandão, F.P., Pereira, J.L., Gonçalves, F., Nunes, B., 2014. The impact of paracetamol on selected biomarkers of the mollusc species Corbicula fluminea. Environ. Toxicol. 29, 74-83, http://dx.doi.org/10.1002/tox.20774.

Burmester, V., Nimptsch, J., Wiegand, C., 2012. Adaptation of freshwater mussels to cyanobacterial toxins: response of the biotransformation and antioxidant enzymes. Ecotoxicol. Environ. Saf. 78, 296-309, http://dx.doi.org/10.1016/j. ecoenv.2011.11.037.

Canesi, L., 2015. Pro-oxidant and antioxidant processes in aquatic invertebrates. Ann. N. Y. Acad. Sci. 1340, 1-7, http://dx.doi.org/10.1111/nyas.12560.

Carlberg, I., Mannervik, B., 1985. Glutathione reductase. Methods Enzymol. 113. 484-490.

Châtel, A., Faucet-Marquis, V., Perret, M., Gourlay-Francé, C., Uher, E., Pfohl-Leszkowicz, A., Vincent-Hubert, F., 2012. Genotoxicity assessment and detoxification induction in Dreissena polymorpha exposed to benzo[a]pyrene. Mutagenesis 27, 703-711, http://dx.doi.org/10.1093/mutage/ges036.

Chen, J., Xie, P., 2005. Seasonal dynamics of the hepatotoxic microcystins in various organs of four freshwater bivalves from the large eutrophic lake Taihu of subtropical China and the risk to human consumption. Environ. Toxicol. 20 572-584, http://dx.doi.org/10.1002/tox.20146.

Choi, N.M.C., Yeung, L.W.Y., Siu, W.H.L., So, I.M.K., Jack, R.W., Hsieh, D.P.H., Wu, R.S.S., Lam, P.K.S., 2006. Relationships between tissue concentrations of paralytic shellfish toxins and antioxidative responses of clams, Ruditapes philippinarum. Mar. Pollut. Bull. 52, 572-578, http://dx.doi.org/10.1016/j. marpolbul.2006.01.009.

Commandeur, J.N.M., Stijntjes, G.J., Vermeulen, N.P.E., 1995. Enzymes and transport systems involved in the formation and disposition of glutathione S-conjugates: role in bioactivation and detoxification mechanisms of xenobiotics. Pharmacol. Rev 47, 271-330.

Contardo-Jara, V., Pflugmacher, S., Wiegand, C., 2008. Multi-xenobiotic-resistance a possible explanation for the insensitivity of bivalves towards cyanobacterial toxins. Toxicon 52, 936-943, http://dx.doi.org/10.1016/j.toxicon.2008.09.005.

Dafre, A.L., Medeiros, I.D., Müller, I.C., Ventura, E.C., Bainy, A.C.D., 2004. Antioxidant enzymes and thiol/disulfide status in the digestive gland of the brown mussel Perna perna exposed to lead and paraquat. Chem. Biol. Interact. 149, 97-105, http://dx.doi.org/10.1016/j.cbi.2004.07.002.

Depledge, M.H., Fossi, M.C., 1994. The role of biomarkers in environmental assessment (2). Invertebr. Ecotoxicol. 3, 161-172, http://dx.doi.org/10.1007/ BF00117081.

de Almeida, E.A., Miyamoto, S., Bainy, A.C.D., de Medeiros, M.H.G., Di Mascio, P., 2004. Protective effect of phospholipid hydroperoxide glutathione peroxidase (PHGPx) against lipid peroxidation in mussels Perna perna exposed to different metals. Mar. Pollut. Bull. 49, 386-392, http://dx.doi.org/10.1016/j.marpolbul. 2004.02.020.

Doyotte, A., Cossu, C., Jacquin, M.-C., Babut, M., Vasseur, P., 1997. Antioxidant enzymes, glutathione and lipid peroxidation as relevant biomarkers of experimental or field exposure in the gills and the digestive gland of the freshwater bivalve Unio tumidus. Aquat. Toxicol. 39, 93-110, http://dx.doi.org 10.1016/S0166-445X(97)00024-6.

Erickson, R.J., McKim, J.M., 1990. A model for exchange of organic chemicals at fish gills: flow and diffusion limitations. Aquat. Toxicol. 18, 175-197, http://dx.doi org/10.1016/0166-445X(90)90001-6.

Franco, J.L., Trivella, D.B.B., Trevisan, R., Dinslaken, D.F., Marques, M.R.F., Bainy, A.C.D., Dafre, A.L., 2006. Antioxidant status and stress proteins in the gills of the brown mussel Perna perna exposed to zinc. Chem. Biol. Interact. 160, 232-240, http://dx.doi.org/10.1016/j.cbi.2006.02.002.

Géret, F., Jouan, A., Turpin, V., Bebianno, M.J., Cosson, R.P., 2002. Influence of meta exposure on metallothionein synthesis and lipid peroxidation in two bivalve mollusks: the oyster (Crassostrea gigas) and the mussel (Mytilus edulis). Aquat. Living Resour. 15, 61-66, http://dx.doi.org/10.1016/S0990-7440(01)01147-0.

George, S.G., Pirie, B.J.S., Cheyne, A.R., Coombs, T.L., Grant, P.T., 1978. Detoxication of metals by marine bivalves: an ultrastructural study of the compartmentation of copper and zinc in the oyster Ostrea edulis. Mar. Biol. 45 147-156, http://dx.doi.org/10.1007/BF00390550.

Ghersi-Egea, J.-F., Strazielle, N., Murat, A., Jouvet, A., Buénerd, A., Belin, M.-F., 2006. Brain protection at the blood-cerebrospinal fluid interface involves a glutathione-dependent metabolic barrier mechanism. J. Cereb. Blood Flow Metab. 26, 1165-1175, http://dx.doi.org/10.1038/sj.jcbfm.9600267.

Gonzalez-Rey, M., Bebianno, M.J., 2011. Non-steroidal anti-inflammatory drug (NSAID) ibuprofen distresses antioxidant defense system in mussel Mytilus galloprovincialis gills. Aquat. Toxicol. 105, 264-269, http://dx.doi.org/10.1016/j. aquatox.2011.06.015.
Hédouin, L., Metian, M., Teyssié, J.-L., Fichez, R., Warnau, M., 2010. Delineation of heavy metal contamination pathways (seawater, food and sediment) in tropical oysters from New Caledonia using radiotracer techniques. Mar. Pollut. Bull. 61, 542-553, http://dx.doi.org/10.1016/j.marpolbul.2010.06.037.

Habig, W.H., Jakoby, W.B., 1981. Assays for differentiation of glutathione S-transferases. Methods Enzymol. 77, 398-405.

Haj-Yehia, A.I., Benet, L.Z., 1996. In vivo depletion of free thiols does not account for nitroglycerin-induced tolerance: a thiol-nitrate interaction hypothesis as an alternative explanation for nitroglycerin activity and tolerance. J. Pharmacol. Exp. Ther. 278, 1296-1305.

Haufroid, V., Lison, D., 2005. Mercapturic acids revisited as biomarkers of exposure to reactive chemicals in occupational toxicology: a minireview. Int. Arch. Occup. Environ. Health 78, 343-354.

Hayes, J.D., Strange, R.C., 2000. Glutathione S-transferase polymorphisms and their biological consequences. Pharmacoly 61, 154-166.

Hayes, J.D., Flanagan, J.U., Jowsey, I.R., 2005. Glutathione transferases. Annu. Rev. Pharmacol. Toxicol. 45, 51-88, http://dx.doi.org/10.1146/annurev.pharmtox. 45.120403.095857.

Hayton, W.L., Barron, M.G., 1990. Rate-limiting barriers to xenobiotic uptake by the gill. Environ. Toxicol. Chem. 9, 151-157, http://dx.doi.org/10.1002/etc. 5620090204

Heiss, E., Gerhäuser, C., 2005. Time-dependent modulation of thioredoxin reductase activity might contribute to sulforaphane-mediated inhibition of NF- $\kappa$ B binding to DNA. Antioxid. Redox Signal. 7, 1601-1611, http://dx.doi.org/ 10.1089/ars.2005.7.1601.

Hinchman, C.A., Ballatori, N., 1994. Glutathione conjugation and conversion to mercapturic acids can occur as an intrahepatic process. J. Toxicol. Environ. Health 41, 387-409, http://dx.doi.org/10.1080/15287399409531852.

Hinchman, C.A., Matsumoto, H., Simmons, T.W., Ballatori, N., 1991. Intrahepatic conversion of a glutathione conjugate to its mercapturic acid. Metabolism of 1-chloro-2,4-dinitrobenzene in isolated perfused rat and guinea pig livers. J. Biol. Chem. 266, 22179-22185.

Jacquoilleot, S., Sheffield, D., Olayanju, A., Sison-Young, R., Kitteringham, N.R., Naisbitt, D.J., Aleksic, M., 2015. Glutathione metabolism in the HaCaT cell line as a model for the detoxification of the model sensitisers 2,4-dinitrohalobenzenes in human skin. Toxicol. Lett. 237, 11-20, http://dx. doi.org/10.1016/j.toxlet.2015.05.016.

James, M.O., 1987. Conjugation of organic pollutants in aquatic species. Environ. Health Perspect. 71, 97-103.

Lüchmann, K.H., Mattos, J.J., Siebert, M.N., Granucci, N., Dorrington, T.S., Bícego, M.C., Taniguchi, S., Sasaki, S.T., Daura-Jorge, F.G., Bainy, A.C.D., 2011. Biochemical biomarkers and hydrocarbons concentrations in the mangrove oyster Crassostrea brasiliana following exposure to diesel fuel water-accommodated fraction. Aquat. Toxicol. 105, 652-660, http://dx.doi.org/ 10.1016/j.aquatox.2011.09.003.

Lüchmann, K.H., Dafre, A.L., Trevisan, R., Craft, J.A., Meng, X., Mattos, J.J., Zacchi, F.L. Dorrington, T.S., Schroeder, D.C., Bainy, A.C.D., 2014. A light in the darkness: new biotransformation genes, antioxidant parameters and tissue-specific responses in oysters exposed to phenanthrene. Aquat. Toxicol. 152, 324-334, http://dx.doi.org/10.1016/j.aquatox.2014.04.021.

Lay, M.M., Menn, J.J., 1979. Mercapturic acid occurrence in fish bile: a terminal product of metabolism of the herbicide molinate. Xenobiotica 9, 669-673.

Liu, D., Pan, L., Cai, Y., Li, Z., Miao, J., 2014. Response of detoxification gene mRNA expression and selection of molecular biomarkers in the clam Ruditapes philippinarum exposed to benzo[a]pyrene. Environ. Pollut. 189, 1-8, http://dx. doi.org/10.1016/j.envpol.2014.02.013.

Livak, K.J., Schmittgen, T.D., 2001. Analysis of relative gene expression data using real-time quantitative PCR and the 2- $\Delta \Delta C T$ method. Methods 25, 402-408, http://dx.doi.org/10.1006/meth.2001.1262.

Livingstone, D.R., Farrar, S.V., 1984. Tissue and subcellular distribution of enzyme activities of mixed-function oxygenase and benzo[a]pyrene metabolism in the common mussel Mytilus edulis L. Sci. Total Environ. 39, 209-235, http://dx.doi. org/10.1016/0048-9697(84)90080-9.

Lu, S.C., 2013. Glutathione synthesis. Biochim. Biophys. Acta 1830, 3143-3153, http://dx.doi.org/10.1016/j.bbagen.2012.09.008.

Luckenbach, T., Altenburger, R., Epel, D., 2008. Teasing apart activities of different types of $A B C$ efflux pumps in bivalve gills using the concepts of independent action and concentration addition. Mar. Environ. Res. 66, 75-76, http://dx.doi. org/10.1016/j.marenvres.2008.02.027.

Macías-Mayorga, D., Laiz, I., Moreno-Garrido, I., Blasco, J., 2015. Is oxidative stress related to cadmium accumulation in the Mollusc Crassostrea angulata? Aquat. Toxicol. 161, 231-241, http://dx.doi.org/10.1016/j.aquatox.2015.02.007.

Malbrouck, C., Kestemont, P., 2006. Effects of microcystins on fish. Environ. Toxicol Chem. 25, 72-86, http://dx.doi.org/10.1897/05-029R.1.

Malins, D.C., Roubal, W.T., 1982. Aryl sulfate formation in sea urchins (Strongylocentrotus droebachiensis) ingesting marine algae (Fucus distichus) containing 2,6-dimethylnaphthalene. Environ. Res. 27, 290-297.

Maria, V.L., Santos, M.A., Bebianno, M.J., 2009. Biomarkers of damage and protection in Mytilus galloprovincialis cross transplanted in Ria Formosa Lagoon (Portugal). Ecotoxicology 18, 1018-1028, http://dx.doi.org/10.1007/ s10646-009-0361-y.

Mello, D.F., de Oliveira, E.S., Vieira, R.C., Simoes, E., Trevisan, R., Dafre, A.L., Barracco, M.A., 2012. Cellular and transcriptional responses of Crassostrea gigas hemocytes exposed in vitro to brevetoxin (PbTx-2). Mar. Drugs 10, 583-597, http://dx.doi.org/10.3390/md10030583. 
Mello, D.F., Arl, M., Trevisan, R., Dafre, A.L., 2015. How important are glutathione and thiol reductases to oyster hemocyte function? Fish Shellfish Immunol. 46, 566-572, http://dx.doi.org/10.1016/j.fsi.2015.07.017.

Metian, M., Hédouin, L., Eltayeb, M.M., Lacoue-Labarthe, T., Teyssié, J.-L., Mugnier C., Bustamante, P., Warnau, M., 2010. Metal and metalloid bioaccumulation in the Pacific blue shrimp Litopenaeus stylirostris (Stimpson) from New Caledonia: laboratory and field studies. Mar. Pollut. Bull. 61, 576-584, http://dx.doi.org 10.1016/j.marpolbul.2010.06.035.

Morré, D.J., Morré, D.M., 1995. Differential response of the NADH oxidase of plasma membranes of rat liver and hepatoma and HeLa cells to thiol reagents. J. Bioenerg. Biomembr. 27, 137-144, http://dx.doi.org/10.1007/BF02110341.

Mostofa, K.M.G., Liu, C.-Q., Vione, D., Gao, K., Ogawa, H., 2013. Sources, factors, mechanisms and possible solutions to pollutants in marine ecosystems. Environ. Pollut. 182, 461-478, http://dx.doi.org/10.1016/j.envpol.2013.08.005.

Murphy, M.E., Scholich, H., Sies, H., 1992. Protection by glutathione and other thio compounds against the loss of protein thiols and tocopherol homologs during microsomal lipid peroxidation. Eur. J. Biochem. 210, 139-146, http://dx.doi. org/10.1111/j.1432-1033.1992.tb17401.x.

Navarro, A., Weißbach, S., Faria, M., Barata, C., Piña, B., Luckenbach, T., 2012. Abcb and Abcc transporter homologs are expressed and active in larvae and adults of zebra mussel and induced by chemical stress. Aquat. Toxicol. 122-123, 144-152, http://dx.doi.org/10.1016/j.aquatox.2012.06.008.

Nogueira, L., Garcia, D., Trevisan, R., Sanches, A.L.M., da Silva Acosta, D., Dafre, A.L., Oliveira, T.Y.K., de Almeida, E.A., 2015. Biochemical responses in mussels Pern perna exposed to diesel B5. Chemosphere 134, 210-216, http://dx.doi.org/10. 1016/j.chemosphere.2015.04.034.

Osman, A.M., Heuvel, van den, H., Noort, van, P.C.M., 2007. Differential responses of biomarkers in tissues of a freshwater mussel, Dreissena polymorpha, to the exposure of sediment extracts with different levels of contamination. J. Appl. Toxicol. 27, 51-59, http://dx.doi.org/10.1002/jat.1183.

Peña-Llopis, S., Serrano, R., Pitarch, E., Beltrán, E., Ibáñez, M., Hernández, F., Peña, J.B., 2014. N-Acetylcysteine boosts xenobiotic detoxification in shellfish. Aquat. Toxicol. 154, 131-140, http://dx.doi.org/10.1016/j.aquatox.2014.05.006.

Pflugmacher, S., 2004. Promotion of oxidative stress in the aquatic macrophyte Ceratophyllum demersum during biotransformation of the cyanobacterial toxin microcystin-LR. Aquat. Toxicol. 70, 169-178.

Pham, R.T., Gardner, J.L., Gallagher, E.P., 2002. Conjugation of 4-hydroxynonenal by largemouth bass (Micropterus salmoides) glutathione S-transferases. Mar. Environ. Res. 54, 291-295.

Ramsay, E.E., Dilda, P.J., 2014. Glutathione S-conjugates as prodrugs to target drug-resistant tumors. Front. Pharmacol. 11, 181, http://dx.doi.org/10.3389/ fphar.2014.00181.

Ravera, O., 2001. Monitoring of the aquatic environment by species accumulator of pollutants: a review. J. Limnol. 60, 63, http://dx.doi.org/10.4081/jlimnol.2001. s1.63.

Renaud, F., Warnau, M., Oberhänsli, F., Teyssié, J.-L., Temara, A., Rouleau, C., Metian, M., 2014. Bioconcentration of the anionic surfactant linear alkylbenzene sulfonate (LAS) in the marine shrimp Palaemonetes varians: a radiotracer study. Mar. Pollut. Bull. 85, 244-247, http://dx.doi.org/10.1016/j.marpolbul.2014.06. 023.

Schröder, P., Scheer, C.E., Diekmann, F., Stampfl, A., 2007. Plants cope with foreign compounds. Translocation of xenobiotic glutathione conjugates in roots of barley (Hordeum vulgare). Environ. Sci. Pollut. Res. Int. 14, 114-122, http://dx. doi.org/10.1065/espr2006.10.352.

Seyfried, J., Wüllner, U., 2007. Inhibition of Thioredoxin reductase induces apoptosis in neuronal cell lines: role of glutathione and the MKK4/JNK pathway. Biochem. Biophys. Res. Commun. 359, 759-764, http://dx.doi.org/10. 1016/j.bbrc.2007.05.176

Silber, P.M., Gandolfi, A.J., Brendel, K., 1986. Adaptation of a $\gamma$-glutamyl transpeptidase assay to microtiter plates. Anal. Biochem. 158, 68-71, http://dx. doi.org/10.1016/0003-2697(86)90590-7.

Simmons, T.W., Hinchman, C.A., Ballatori, N., 1991. Polarity of hepatic glutathione and glutathione S-conjugate efflux: and intraorgan mercapturic acid formation in the skate. Biochem. Pharmacol. 42, 2221-2228.

Solé, M., Livingstone, D.R., 2005. Components of the cytochrome P450-dependent monooxygenase system and NADPH-independent benzo[a]pyrene hydroxylase activity in a wide range of marine invertebrate species. Comp. Biochem. Physiol. C 141, 20-31, http://dx.doi.org/10.1016/j.cca.2005.04.008.

Stoelting, M.S., Tjeerdema, R.S., 2000. Glutathione-dependent biotransformation of 1-chloro-2,4-dinitrobenzene in arterial and venous blood of the striped bass (Morone saxitilis). Aquat. Toxicol. 50, 177-187, http://dx.doi.org/10.1016/ S0166-445X(99) 00107-1.

Tedesco, S., Doyle, H., Blasco, J., Redmond, G., Sheehan, D., 2010. Exposure of the blue musse. Mytilus edulis, to gold nanoparticles and the pro-oxidant menadione. Comp. Biochem. Physiol. C 151, 167-174, http://dx.doi.org/10. 1016/j.cbpc.2009.10.002.

Terlouw, S.A., Masereeuw, R., Van Den Broek, P.H.H., Notenboom, S., Russel, F.G.M. 2001. Role of multidrug resistance protein 2 (MRP2) in glutathione-bimane efflux from Caco-2 and rat renal proximal tubule cells. Br. J. Pharmacol. 134, 931-938, http://dx.doi.org/10.1038/sj.bjp.0704284.
Trevisan, R., Ferraz Mello, D., Fisher, A.S., Schuwerack, P.-M., Dafre, A.L., Moody, A.J., 2011. Selenium in water enhances antioxidant defenses and protects against copper-induced DNA damage in the blue mussel Mytilus edulis. Aquat. Toxicol. 101, 64-71, http://dx.doi.org/10.1016/j.aquatox.2010.09.003.

Trevisan, R., Arl, M., Sacchet, C.L., Engel, C.S., Danielli, N.M., Mello, D.F., Brocardo, C., Maris, A.F., Dafre, A.L., 2012. Antioxidant deficit in the gills of Pacific oyster (Crassostrea gigas) exposed to chlorodinitrobenzene increases menadione toxicity. Aquat. Toxicol. 108, 85-93, http://dx.doi.org/10.1016/j.aquatox.2011. 09.023 .

Trevisan, R., Delapedra, G., Mello, D.F., Arl, M., Schmidt, É.C., Meder, F., Monopoli, M., Cargnin-Ferreira, E., Bouzon, Z.L., Fisher, A.S., Sheehan, D., Dafre, A.L. 2014a. Gills are an initial target of zinc oxide nanoparticles in oysters Crassostrea gigas, leading to mitochondrial disruption and oxidative stress. Aquat. Toxicol. 153, 27-38, http://dx.doi.org/10.1016/j.aquatox.2014.03.018.

Trevisan, R., Flesch, S., Mattos, J.J., Milani, M.R., Bainy, A.C.D., Dafre, A.L., 2014b. Zinc causes acute impairment of glutathione metabolism followed by coordinated antioxidant defenses amplification in the gills of brown mussels Perna perna. Comp. Biochem. Physiol. C 159, 22-30, http://dx.doi.org/10.1016/ j.cbpc.2013.09.007.

Trevisan, R., Mello, D.F., Uliano-Silva, M., Delapedra, G., Arl, M., Dafre, A.L., 2014c. The biological importance of glutathione peroxidase and peroxiredoxin backup systems in bivalves during peroxide exposure. Mar. Environ. Res. 101, 81-90, http://dx.doi.org/10.1016/j.marenvres.2014.09.004.

Uršič, D., Berginc, K., Žakelj, S., Kristl, A., 2009. Influence of luminal monosaccharides on secretion of glutathione conjugates from rat small intestine in vitro. Int. J. Pharm. 381, 199-204, http://dx.doi.org/10.1016/j. ijpharm.2009.03.011, Challenges in Nano- Micro- and Macro-Systems.

Vaidya, S.S., Gerk, P.M., 2007. Simultaneous determination of 1-chloro-2,4-dinitrobenzene, 2,4-dinitrophenyl-S-glutathione and its metabolites for human placental disposition studies by high-performance liquid chromatography. J. Chromatogr. B 859, 94-102, http://dx.doi.org/10. 1016/j.jchromb.2007.09.006.

Vaidya, S.S., Walsh, S.W., Gerk, P.M., 2011. Application of human placental villous tissue explants to study ABC transporter mediated efflux of 2,4-dinitrophenyl-S-glutathione. Curr. Pharm. Biotechnol. 12, 814-823.

Villanueva, S.S.M., Ruiz, M.L., Luquita, M.G., Pozzi, E.J.S., Catania, V.A., Mottino, A.D. 2005. Involvement of Mrp2 in hepatic and intestinal disposition of dinitrophenyl-S-glutathione in partially hepatectomized rats. Toxicol. Sci. 84 4-11, http://dx.doi.org/10.1093/toxsci/kfio53.

Villanueva, S.S.M., Ruiz, M.L., Soroka, C.J., Cai, S.-Y., Luquita, M.G., Torres, A.M., Pozzi, E.J.S., Pellegrino, J.M., Boyer, J.L., Catania, V.A., Mottino, A.D., 2006. Hepatic and extrahepatic synthesis and disposition of dinitrophenyl-S-glutathione in Bile Duct-ligated rats. Drug Metab. Dispos. 34 1301-1309, http://dx.doi.org/10.1124/dmd.106.009415.

Wang, Z., Plakas, S.M., El Said, K.R., Jester, E.L.E., Granade, H.R., Dickey, R.W., 2004 LC/MS analysis of brevetoxin metabolites in the Eastern oyster (Crassostrea virginica). Toxicon 43, 455-465, http://dx.doi.org/10.1016/j.toxicon.2004.02. 017.

Whalen, K.E., Sotka, E.E., Goldstone, J.V., Hahn, M.E., 2010. The role of multixenobiotic transporters in predatory marine molluscs as counter-defense mechanisms against dietary allelochemicals. Comp. Biochem. Physiol. C 152, 288-300, http://dx.doi.org/10.1016/j.cbpc.2010.05.003.

Yagen, B., Foureman, G.L., Ben-Zvi, Z., Ryan, A.J., Hernandez, O., Cox, R.H., Bend, J.R., 1984. The metabolism and excretion of 14C-styrene oxide-glutathione adducts administered to the winter flounder, Pseudopleuronectes americanus, a marine teleost. Identification of the corresponding S-cysteine derivatives as major urinary metabolites. Drug Metab. Dispos. 12, 389-395.

Zablotowicz, R.M., Hoagland, R.E., Locke, M.A., Hickey, W.J., 1995 Glutathione-s-transferase activity and metabolism of glutathione conjugates by rhizosphere bacteria. Appl. Environ. Microbiol. 61, 1054-1060.

Zanette, J., Nunes, F.F., Medeiros, I.D., Siebert, M.N., Mattos, J.J., Lüchmann, K.H., Melo, C.M.R., de, Bainy, A.C.D., 2008. Comparison of the antioxidant defense system in Crassostrea rhizophorae and Crassostrea gigas exposed to domestic sewage discharges. Mar. Environ. Res. 66, 196-198, http://dx.doi.org/10.1016/j. marenvres.2008.02.057.

Zanette, J., de Almeida, E.A., da Silva, A.Z., Guzenski, J., Ferreira, J.F., Di Mascio, P., Marques, M.R.F., Bainy, A.C.D., 2011. Salinity influences glutathione S-transferase activity and lipid peroxidation responses in the Crassostrea gigas oyster exposed to diesel oil. Sci. Total Environ. 409, 1976-1983, http://dx.doi. org/10.1016/j.scitotenv.2011.01.048.

Zhang, K., Wong, K.P., 1996. Active transport of glutathione S-conjugate in human colon adenocarcinoma cells. Cancer Lett. 108, 143-151, http://dx.doi.org/10. 1016/S0304-3835(96) 04457-6. 